Çeviri Makaleleri

Translation Articles 


\begin{tabular}{r|l} 
UMDE DiNi TETKIKLER DERGisi & Makale Türü / Article Type: Çeviri Makalesi / Translation Article \\
UMDE JOURNAL OF RELIGIOUS INQUIRIES & Geliș Tarihi / Received: 16.08 .2021 \\
Cilt/Volume: 4, Sayı/Issue: 2 (Aralık/December 2021): 259-290 & Kabul Tarihi / Accepted: 18.12 .2021 \\
& Yayın Tarihi / Published: 31.12 .2021
\end{tabular}

\title{
Güçlü Bir Tetikleyici mi Tökezleten Bir Engel mi: Klasik Tasavvufta Anne İmgeleri ve Rolleri* $^{*}$
}

\section{Arin Shawkat Salamah-Qudsi **}

Çev. Zeynep İrem Çeven***

\author{
Sevgili Babam Shawkat Salamah'ın sevgi dolu anısına: \\ Ĕ̌er birinin yarenliğinden hoșnut kaldlysam \\ O da annemin yarenliğiydi. \\ O sadece bir kadın değildi, \\ Aynı zamanda rûhâni bir adamdı! \\ Ferîdüddin Attâr, Hüsrevnâme,
}

Akt. Javad Nurbaksh, Sufi Women (New York, 1983), 9.

\begin{abstract}
Öz: Tasavvuf kaynaklarında anne-çocuk ilişkisi hakkında az sayıda detay verilmiş olsa da hem kendisi sûfî olanlar hem de yalnızca tanınmış sûfîlerin annesi olarak bilinenler, sıklıkla annelik kavramılla uyumlu "geleneksel"1 imgelerin ötesinde davranmıştır. Anneler her zaman çocukları için etkili, güçlü bir tetikleyici olmamış hatta bazen tabakat yazarlarının da bahsettiği “anne hakkı"nın (hakku'l-vâlide) kendilerine sağladığı imkânın ve anneye saygı ilkesinin avantajını kullanarak, oğullarının rahatça
\end{abstract}

* Arin Salamah-Qudsi, “A Lightning Trigger or a Stumbling Block: Mother Images and Roles in Classical Sufism”, Oriens 39/2 (Jan 2011), 199-226.

Eserin yazarı Arin Shawkat Salamah-Qudsi'den ve yayın haklarını elinde bulunduran Brill'den makalenin tercüme edilip, yayımlanması için yazılı izin alınmıștır. Tercümede, anlam bütünlüğünü sağlamak amacıyla eklenen ifadeler [] köşeli parantezle belirtilmiștir. (çev. notu)

** Dr. Arin Shawkat Salamah-Qudsi, Hayfa Üniversitesi, Arap Dili ve Edebiyatı Bölümü, Hayfa İsrail.

Dr. Arin Shawkat Salamah-Qudsi, University of Haifa, Department of Arabic Language and Literature, Haifa Israel.

arinsq@gmail.com orcid.org/0000-0001-6803-0802.

*** Zeynep İrem Çeven, Doktora Öğrencisi, İstanbul Üniversitesi, Sosyal Bilimler Enstitüsü, Temel İslam Bilimleri Anabilim Dalı, Tasavvuf Bilim Dalı, İstanbul Türkiye.

Zeynep İrem Çeven, Ph.D. Student, Istanbul University, Institute of Social Sciences, Department of Basic Islamic Sciences, Department of Sufism, Istanbul Turkey.

ziremceven@gmail.com orcid.org/0000-0002-6672-8921.

1 Makalede geçen “iconic" kelimesi için "geleneksel” ifadesi tercih edilmiştir.

Atıf / Cite as: Ceven, Zeynep İrem. "Güçlü Bir Tetikleyici mi Tökezleten Bir Engel mi: Klasik Tasavvufta Anne İmgeleri ve Rolleri”. UMDE Dini Tetkikler Dergisi-UMDE Journal of Religious Inquires 4/2 (Aralı/December 2021): 259-290 https://doi.org/10.54122/ umde. 983639 


\begin{abstract}
seyahat etmesini engellemişlerdir. Tasavvuf dünyasında dayılar, destekleyici anne idealine, annelerden daha etkili bir katkı sunmuş gibi görünmektedir. Bu makale, 2009 -2010 yıllarında Profesör Binyamin Abrahamov'un danışmanlığında, Bar Ilan Üniversitesi'nde (İsrail) "Evrensel Tektanrıcilik Dangoor Programı" (The Dangoor Program of Universal Monotheism) tarafından destek alarak [hazırladığım] doktora sonrası araştırma çalışmamın bir parçası olarak yazılmıştır. Başlıktaki "klasik" kelimesi, Fritz Meier'in tasavvufu üç ana aşamaya ayıran sınıflandırmasına atıfta bulunur: pre-klasik tasavvuf (II. /VIII. yüzyılın ikinci yarısından III. /IX. yüzyılın başına kadar), III. /IX. yüzyıldan V./XI. yüzyıla kadar uzanan klasik tasavvuf ve yaklaşı V./XI. yüzyılın sonlarından itibaren süregelen post-klasik tasavvuf. Klasik dönemle birlikte, tasavvuf "homojenlik içinde kazanılmış bir bütün olarak" "ruhani bilimlerin² neredeyse tam bir kümesi” haline gelmiştir [F. Meier, "The Mystic Path”, The World of Islam: Faith, People, Culture, ed. Bernard Lewis (Londra: Thames \& Hudson, 1976), 118]. Dahası postklasik tasavvuf, temel olarak vizyoner ve okült deneyimlerin yüksek değerleri, insandaki ilâhi kıvılcım teorisi (the theory of a divine spark in man) ve dünyanın Tanrı'dan sudûruna ilişkin Gnostik kavramı ile ayırt edilir. Post-klasik dönem boyunca, tasavvuf daha erken dönemlerdeki marjinalliğinin tersine geniş bir popülerlik kazanmayı başarmışıı (bk. Meier, "The Mystic Path”, 120). Terminolojinin bu kullanımı, modern bilim tarafından yapılan diğer tespitlerden biraz farklıdır. [bk. Tonaga Yasushi, "Sufism in the Past and Present", Annals of Japan Association of Middle East Studies, 21 (2006), 12-13]. Meier'in sinıflandırmasına göre, klasik ve erken post-klasik dönemlerindeki tasavvuf, bu makalenin ilgilendiği temel alandır.

Anahtar Kelimeler: Anne hakk1, sıla-i rahim, ebeveyne sayg1 (filial piety)3, alt ruh (lower soul), dayılar.
\end{abstract}

\title{
Giriş
}

Son yıllarda toplumsal cinsiyet ve feminizm üzerine yapılan bilimsel araştırmaların artmasıyla birlikte, annelik farklı bağlamlarda ve araştırma projelerinde daha fazla ilgi görmeye başlamıştır. Modern anneliğin "özünün ortadan kaldırıldığı" yani anneliğin "özcü ve dar bir çerçeve içinde görüldüğ̈̈"4 uzun bir dönemden sonra "anneliğin çeşitli bağlamlarda ele alınması"5 için yeni bir araştırma girişiminde bulunulmuştur. İslam'da anneleri ele alırken, bu görüşü dikkate almak büyük önem teşkil edecektir. Abdelwahab Bouhdiba'nın (1985) “annelerin krallığı” çalışması, genellemelerden tamamıyla yoksun görünmese de oldukça ilginçtir ve orada gündeme getirilen bazı öneriler mevcut tartışmamıza ilham verecektir. ${ }^{6}$ Bu makalenin amacı, tasavvufla olan özel ilişkisi üzerinden

2 Makalede "inner science" olarak ifade edilen bu kavram, tercümede "ruhani bilimler" şeklinde sunulmuştur. (çev. notu)

3 Anne-babaya saygı duymak, itaat etmek, onlarla ilgilenmek, onlara karşı görevlerini yerine getirmek gibi birçok davranışı içeren "filial piety" kavramı, tercümede "ebeveyne saygı" şeklinde sunulmuştur. (çev. notu)

4 Robyn Longhurst, Maternities: Gender, Bodies and Space (New York: Routledge, 2008), 1-146.

5 Longhurst, Maternities, 1-15.

6 bk. Abdelwahab Bouhdiba, "In the Kingdom of the Mothers", çev. Alan Sheridan, Sexuality in Islam (Londra, Boston, Melbourne \& Henley: Routledge, 1985), 212-230. 
annelik meselesine dair bir katkı sunmaktır. Bununla birlikte, toplumsal cinsiyet ve annelik konularında son dönemde yapılan araştırmalar [göz önünde bulundurulduğunda] temel bir yenilik getirdiğimizi iddia etmemekte daha ziyade İslam'ın sosyal alandaki manevi boyutunun bir yönünü ortaya koyduğumuzu ifade etmekteyiz: Tasavvufun III./IX. yüzyıldaki teşekkül döneminden V./XI. yüzyıldaki klasik döneminin sonuna kadar devam eden erken dönemlerinde anne rolleri ve imgeleri. Bildiğim kadarıyla, henüz herhangi bir araştırmada bu konuya temas edilmedi ancak yapılacak çok şey olduğuna inanıyorum, mevcut veriler detaylı ve kapsamlı bir çalışmayı desteklemek için hala çok yetersiz. Bu nedenle bu makale, sonraki araştırmalar için bir çekirdek niteliğindedir.

İlk olarak 1993 senesinde Kahire'de Mahmud et-Tanâhî tarafından yayımlanan, Ebû Abdurrahman es-Sülemînnin (ö. 411/1021) Tabakâtü's-sûfîyye'ye' ek olarak değil de müstakil olarak kurgulayıp yazdığı sûfî kadınlarla ilgili eseriyle, Râbiatü'l-Adeviyye (ö. 185/801) figürüne yönelik oluşan bilimsel "düşkünlük”, tasavvuf alanında yeni kadın figürlere yer açmaya başlamıştır. Müslüman kadınların, ana akım İslam'daki konumlarına kıyasla, İslam tasavvufunda daha saygın bir konum elde etmeyi başardığı varsayımı, yeni ve sağlam delillere dayanır. Ancak bu makale, İslam'ın spiritüel tarihindeki kadınların eşitliği veya eşitsizliği hakkındaki tartışmalara dahil olmayı amaçlamamaktadır. Bunun yerine, erken dönem tasavvuf kaynaklarında annelik konusuna dair ender rastlanan verilerin işaret ettiği, tarihin bu gizli alanına daha fazla ışık tutmayı hedeflemektedir. Bu konuya dair veri eksikliği, başlı başına bir sorun olmasının yanı sıra, bilgi boşluklarının iyi bilinen fikirlerle uyumlu hakim kültürel değerlendirmelerle doldurulmasına neden olur. Tasavvuf literatüründe annelerin ihmali, diğer kültürlerdekinden farklı değildir. Anne-çocuk ilişkisi düşünüldüğünde, bir taraf yani çocuklar hakkında yeterli veri yoksa, diğer tarafın yani annelerin duygusal ve fiili değerlendirmelerini destekleyebilecek neredeyse hiçbir materyal yoktur. Bilhassa tanınmış sûfîlerin eşleri annelerden daha fazla ilgi görmüştür. Bu kıs-

7 bk. Abū Abd ar-Rahmān as-Sulamī, Early Sûfi Women: Dhikr an-niswa al-muta'abbidat as-sufiyyat, çev. Rkia ElarouiCornell (Lousville: Fons Vitae, 1999), 44-45. Bu eserin Türkçe tercümesi için bk. Ebû Abdurrahman es-Sülemî, Kendilerini İbadete Adayan Sufi Kadınlar, çev. Ali Akay (İstanbul: İlk Harf Yayınevi, 2012). (çev. notu).

8 Fatima Mernissi'nin “ilk müslüman tarihçiler yazılarında kadınlara önemli ölçüde yer verdiler” ve "beklendiği gibi onlardan yalnızca güçlü erkeklerin anneleri ya da kızları olarak bahsetmediler [. . .]" şeklindeki sözleri kabul edilebilir. bk. Fatima Mernissi, "Women in Muslim History: Traditional Perspectives and New Strategies", Women and Islam: Critical Concepts in Sociology, ed. Haideh Moghissi (Londra: Taylor \& Francis, 2005), 1/37. Ancak kanaatimce, tarih kitaplarının, soy kütüklerinin ve günlüklerin ortaya koyduğu gibi, "tarihi olaylara aktif katılım gösteren, tam manasiyla müdahil ortaklar" (Mernissi, Women and Islam) olmak, annelerin ve kızların 'annelik ve kız evlatlık' bağlamında, gerçekten tanımlandıkları anlamına gelmez. 
men, tasavvuf tabakatlarında eşliğin erkek mutasavvıfların mübarek karakterlerine bir destek olarak görüldüğü güçlü evlilik kurumundan kaynaklanmaktadır. Evli kadınlardan kocalarının tasavvufi hayatlarına dair ek bir bilgi verdiklerinde bahsedilirken, yaygın bir kanaate göre anneler, genellikle herhangi bir edebi referansa karşı bir engel görevi gören güçlü bir kutsallaştırma geleneği ile çevrelenmiştir.

Yukarıda farklı bağlamlarda değerlendirilen 'annelik' kavramı göz önünde bulundurulduğunda, anneliği tasavvufla olan ilişkisi açısından inceleme niyetimizin sebebi ne olabilir? "Sûfî anneler" veya "sûfi tabakatlarında anne imgeleri" şeklinde ele alınan başlıklarımızdaki bu tür genellemeleri ilgili ve yeterli kılan nedir? Esasen, bu kadınları birleştirmiş olabilecek temel özellik, en azından edebi düzeyde, ihmal edilmiş olmalarıdır. Tarihçiler ve biyografi yazarları, kadın hadis râvîlerinden, tasavvufi bağlamdaki annelere kıyasla daha çok bahsetmektedir. Bu kısa incelemenin konusu, genelleyici bir yaklaşım ifade etmiş olsa da teşekkül dönemindeki tasavvuf düşüncesinin ve pratiklerinin tam kalbinde yer alan sosyal hayatın ve dinamiklerin yeniden inşasına yönelik son girişimlere ekleyecek çok şey barındırmaktadır.

Çalışma ve araştırma yöntemlerine ilişkin tüm eleştirel görüşler bir kenara bırakılırsa, dindar annelerin sûfî oğulları üzerindeki etkisine "Orta Çağ ve modern sûfî biyografilerini dikkatle inceleyen biri için büyüleyici bir konu başlı̆̆ı" olarak dikkat çeken ilk isim Annemarie Schimmel'di. ${ }^{10}$ Schimmel, Mystical Dimensions of Islam (İslam'ın Mistik Boyutları) isimli eserinin ikinci ekinde, "sûfî biyografilerinde annelerin rolünün incelenmeye değer olduğunu" ifade etmiştir." Meine Seele ist eine Frau (Ruhum Bir Kadındır) isimli eserinde de annelerin İslam kültüründeki önemini detaylı bir şekilde tasvir etmektedir. ${ }^{12}$ Schimmel'in düşüncelerinin altında yatan genel varsayım, tasavvufta annelerin oğullarının ma-

9 Metinde "career ve sûfî career" şeklinde sunulan kavramlar için tercümede bağlama göre tasavvufi hayat, tasavvufi yol, tasavvuf yolculuğu ve seyr u sülûk ifadeleri kullanılmıştır. (çev. notu)

10 Annemarie Schimmel, "Women in Mystical Islam", Women and Islam, ed. Aziza al-Hibri (Oxford: Pergamon Press, 1982), 149-150.

11 Annemarie Schimmel, Mystical Dimensions of Islam (Chapel Hill: The University of North Carolina Press, 1975$), 430$. Eserin Türkçe tercümesi için bk. Annemarie Schimmel, İslamın Mistik Boyutları, çev. Ergun Kocabıyık (İstanbul: Alfa Yayınları, 2020). (çev. notu)

12 bk. Annemarie Schimmel, My Soul is a Woman: the Feminine in Islam, çev. Susan H. Ray (New York: Continuum, 1997), 89-97. Bu sayfalar, annelerinin dindarlığının veli erkekler üzerindeki “doğal” etkisini göstermeyi amaçlayan, temelde post-klasik döneme ait tasavvuf literatürünün kısa bir incelemesini göstermektedir. Bu "kutsal annelik" [meselesine] dair ek bir kavrayışa teşebbüs edilmemiştir. Bu eserin Türkçe tercümesi için bk. Annemarie Schimmel, Ruhum Bir Kadındır, çev. Ömer Enis Akbulut (İstanbul: İz Yayıncılık, 2011). (çev. notu) 
nevi liderliğinin oluşumuna katkıda bulunduklarıdır. Aşağıdaki satırlarda, bu varsayımın yanı sıra anne imgesi ve rollerine ilişkin diğer temel kavramlar yeniden ele alınacaktır.

\section{Erken Dönem Tasavvuf Literatüründe Annelere Karşı Eşler}

Bazı toplumsal cinsiyet araştırmacılarının yaptığı gibi hem bir işlev hem de bir düşünce olarak eş ve anne arasındaki farklılıkları savunmak, bu makalenin amaçlarının ötesindedir. Miriam Johnson, Strong Mothers, Weak Wives (1988) isimli eserinde, iki kurum arasında bir ayrım yaparak, eşliğin kadının güçsüzlüğünü ve bağımlıllğını gösterirken, anneliğin kadının gücünü ve otoritesini gösterdiğini savunur. ${ }^{14}$ David Herlihy, pre-modern bağlamda, "annenin prestiji ve hane halkı içindeki etkisi belki de bizim bildiğimizden daha fazlaydı" der. ${ }^{15}$ Annelik ve eşlik arasındaki modern ayrımın getirdiği bazı zımni öneriler, bu makalede sunulan görüşleri destekleyecektir.

Sülemî̀nin Zikru'n-nisve isimli eserindeki seksen iki kişiden on beşi tanınmışs sûfilerin eşleri iken sadece üçü iyi tanınmış şahsiyetlerin anneleri olarak açıkça tarif edilen kadınlardır." Biyografilerin geri kalanı, yalnızca tanınmış erkek ya da kadın mistiklerin kız kardeşlerinin, kızlarının ve cariyelerinin bireysel hikayeleri gibi görünmektedir. Annelere ait üç rivayetten birinde yer verilen Hâlid b. Ma'dân'ın kızı Ümmü Abdullah'ın oğlu, annesinden hadis nakleden döneminin en büyük râvilerinden biri olarak kabul edilir. ${ }^{17}$ Yazar, diğer iki biyografide sûfî anneleriyle oğullarının ilişkilerine herhangi bir atıfta bulunmaktan kaçınırken, biyografilerin başında oğulların isimlerini aktarır. ${ }^{10}$

Pre-modern dönemde, Tanrı'ya kulluk eden sûfî bir kadın olmak, sıradan kadınların elde etmesine izin verilmeyen sosyal ve kamusal özgürlüğü elde etmek demekti. Bu durum erkek sûfîlerle görüşmeyi, eğitim (öğretme ve öğrenme) süreçlerine aktif katılımı ve bir-

13 Metinde eş olarak kullanılan bütün ifadeler kadın için kullanılmıştır.

14 bk. Miriam M. Johnson, Strong Mothers, Weak Wives: The Search for Gender Equality (Berkeley, Los Angeles \& Londra: University of California Press, 1988), 5-8, 37-40.

15 David Herlihy, Medieval Households (Cambridge: Harvard University Press, 1985), 129.

16 Sülemî'de diğer niteliklerinin yanı sıra anne olarak da tasvir edilen sûfî kadınlar için bk. Sulamī, Dhikr, 101, 215, 239.

17 Söz konusu kişi İsmâil b. Ayyâş’tır. bk. Sulamī, Dhikr, 100, not 43; Ebû Abdirrahmân es-Sülemî, Tabakātü’ṣ-șuffiyye, ed. Johannes Pedersen (Leiden: Brill, 1960), 407. Bu eserin Türkçe tercümesi için bk. Ebû Abdurrahman esSülemî, İlk Zâhid ve Sûfiler- Tabakâtu's-Sûfiyye, çev. Abdurrezzak Tek (Bursa: Bursa Akademi, 2018). (çev. notu)

18 bk. Sulamī, Dhikr, 215, 239. 
çok durumda yeni manevi bilgi ve deneyim arayışında kendi ailelerini geride bırakmayı içerirdi. Eşlerin, erkek sûfîlerin meydan okumak zorunda olduğu en büyük "düşmanlardan" biri19 hatta daha da kötüsü, "cehennem ateşinin ikamesi”20 olarak tasvir edildiği erken dönem tasavvuf eserlerindekinin aksine Sülemînnin "eşleri” çok daha saygın bir üslupla tasvir edilmiştir. Dindar erkeklerin eşleri, kocalarının seyr u sülûk süreçlerinde annelere göre çok daha fazla yer almışlardır. Kocalar kendilerini tasavvuf yoluna adamaya karar verdiklerinde, sıklıkla kadınların ailelerinin geçimini isteyerek üstlendikleri söylenirdi. Diğer durumlarda zengin kadınlar, sûfî eşlerinin tüm yoldaşlarını maddi olarak destekleyebildiler, Ahmed b. Ebü'l-Havârînnin eşi Râbia bint İsmâil (ö. 230/845) buna örneklik teşkil eder. ${ }^{21}$ Kesin verilere göre, Râbia'nın cinsel ilişkiye hiç ilgisi yoktu ve sonunda kocasından, başka bir kadınla evlenmesini istedi. Dindar bir sûfî olan kocasını, diğer eşlerini cinsel açıdan tatmin etmesi için cesaretlendirirken, yemek pişirmek gibi eşlik görevlerine bağlı kaldı.22 "Maneviyatı güçlü bir çiftin" düzenli cinsel yaşamdan tamamen uzak durabilecekleri bir dereceye kadar bekar yaşamı seçmeleri, çoğunlukla ütopik bir idealdi. Bu tür durumlar, uzun süre boyunca erkek sûfîlere atfedilmişti ancak sonunda kadınların biyografilerinde de eşdeğerleri bulundu. Bazı durumlarda, aslında kadınlar bekar yaşamayı seçmişti. Örneğin, İbnü'z-Zeyyât et-Tâdilî̀nin VI./XII. yüzyll Kuzey Afrika biyografisi, Kitâbü't -Tasavvuf ilâ Ricâli't-Tasạvvuf, gerçek bir inziva idealini çok ciddiye almış görünen kadın figürleriyle doludur. ${ }^{23}$ Bazı kaynaklar, Râbia bint İsmâil'in ilk kocasından kendisine miras kalan malı harcayarak hem Ahmed b. Ebü'l-Havârîye hem de sûfî arkadaşlarına "hizmet

19 bk. Ebû Tâlib el-Mekkî, Kūtü'l-kulûb (Kahire: Mușṭafā al-Bābī al-Ḥalabī, 1961), 2/490-492. Serrâc et-Tûsî (ö. 377/988), bir grup sûfînin cinsel arzudan "korunmak" için cinsel organlarını kesmeye çalıştıklarının söylendiğini bildirir. bk. Abū Nasr al-Sarrāj, al-Luma' fil-tasawwuf, ed. R.A. Nicholson (Leiden: Brill, 1914), 418; Alī b. Uthmān al -Jullābī al-Hujwīrī, The Kashf al-mahjūb, çev. R.A. Nicholson (Londra: E.J.W. Gibb Memorial \& Luzac, 1976), 364365. Bu üç eserin Türkçe tercümeleri için bk. Ebû Tâlib el-Mekkî, Kûtü'l-Kulûb, çev. Muharrem Tan (İstanbul: İz Yayıncılık, 2018); Ebû Nasr Serrâc Tûsî, el-Lumâ- İslâm Tasavvufu, çev. Hasan Kâmil Yılmaz (İstanbul: Erkam Yayınları, 2012); Hücvirî, Hakikat Bilgisi- Keşfu'l-Mahcûb, çev. Süleyman Uludağ (İstanbul: Dergah Yayınları, 1982). (çev. notu)

20 A. Schimmel, "Eros in Sûfî Literature and Life", Society and the Sexes in Medieval Islam, ed. Afaf Lutfi al-SayyidMarsot (Malibu: Undena Publications, 1979), 127; Mekkî, Kūtü'l-kulûb, 2/492.

21 Sulamī, Dhikr, 139. bk. İbn Hamîs el-Mevsılî, Menâkıbü'l-ebrâr ve mehâsinü'l-ahyâr, ed. Said Abdülfettâh (Beyrut: Dârü'l-kütübi'l-ilmiyye, 2006), 1/153 (Serî es-Sakatî’nin kız kardeși (ö. 257/870) hakkında).

22 bk. Mekkî, Kūtü'l-kulûb, 2/507.

23 bk. Yusuf b. Yahya İbnü'z-Zeyyât, et-Teşevvüf ilâ Ricâli't-Tasavvuf, ed. Ahmed Tevfik (Ribât: Menşûrâtü Külliyyeti'lÂdâb, 1997), 94. 
cıyla bu evliliği istediğini belirtir. ${ }^{24}$ Tasavvuf tarihinde, kadınların tanınmış sûfîlerle evlenmek istemesi nadir değildi. ${ }^{25}$ Dahası, bazı durumlarda bu teklifler reddedilirdi. ${ }^{26}$

Bizim izlenimimiz, Sülemî’nin Zikr'indeki tanınmış erkek sûfîlerin eşlerinin tasvirlerinin, kocalarının maneviyatına dair ek bir bilgiyi ortaya çıkarmak için tasarlanmadığı, daha ziyade kadın sûfîlerin kendilerine özgü yaşam tarzlarına ve düşüncelerine 1şık tutmaya yönelik bir girişim olduğudur. ${ }^{27}$ Bazıları bunun aynı zamanda erkek maneviyatını övmek için bir yöntem olduğunu iddia etse de Sülemînin birçok biyografisinde görüldüğü gibi, dindar evli kadınları yasalar açısından daha aşağıda oldukları halde, bilgileri ve manevi kapasiteleri sebebiyle, sûfî kocalarından üstün kılmak, erken dönem tasavvufunda eşlerin gerçekte oynadığı ufuk açıcı rolün bir delili olarak görülebilir. ${ }^{28}$ Müslüman tabakat yazarlarının evli bir kadının statüsünü belirtmek için sıklıkla "taht" (altında) ifadesini kullandığını fark etmek ilginçtir. ${ }^{29}$ Bununla birlikte, Sülemî'nin Zikr'i ve İbnü'l-Cevzî'nin Sıfatü'sSafve'sindeki dindar kadınlarla ilgili bölümlerde olduğu gibi kullanılan terim çoğunlukla zevcedir. ${ }^{30}$ Sûfîlerin, kadınlardan maddi destek almaya teşvik edilmediği ünlü gelenek (rıfk çoğulu erfâk) ${ }^{31}$ büyük olasılıkla bu alışkanlığın müslüman toplumlarda ulaştı̆̆ı popülerliğin derecesine bir cevaptır.

24 bk. Mükerrem İbn Manzûr, Muhtasaru Târîhi Dımaşk, ed. Ma'mûn es-Segercî (Şam: Dârü'l-fikr, 1984), 8/347; Sulamī, Dhikr, 139. VI./XII. yüzyıl sûfî söyleminde, sûfîlerin maddi desteğinin bir göstergesi olarak "hizmet" kavramı için bk. Arin Salamah Qudsi, "The Idea of Tashabbuh in Sufi Communities and Literature of the Late 6th/12th and Early 7th/13th Century in Baghdad", al-Qantara 32/1 (2011), 189-197.

25 bk. Hujwīī̄, Kashf al-mahjūb, 120; Abdurrahman Câmî, Nefehâtü'l-üns, ed. Mehdî Pur (Tahran: Intişââ̂t-1 kitâbfurûşî Mahmûdî, 1918), 101.

26 bk. Câmî, Nefehâtü'l-üns, 101, 331.

27 bk. Sulamī, Dhikr, 163, 169, 187, 201, 207.

28 Muhammed b. Abdirrahmân es-Sehâvî, ed-Dav 'ü'l-lâmi 'li-ehli'l karni't-tâsi (Beyrut: Dâr Mektebetü'l-hayâ, ts.), 12 (Mu'cemu'n-nisâ)/ 2. Arapça ifade hala belirsizdir; ikinci cümlenin (ve lem yertedî emrahe' fe-fe'rakahe') birinci cümlenin sonucu olduğuna emin olunamaz: (ve haccet me'ahu ve me’a gayrihi)

29 bk. Yahyâ b. Şerefeddin en-Nevevî, Riyâzü̈s-Sâlihîn min kelâm seyyîd el-mürselin (Kahire: Mektebet Misır, 1995), 102; Ebü'l-Kâsım Alî b. Hasen '̇̇bn Asâkir, Târîhu medîneti Dımaşk: Terâcimu'n-nisâ, ed. Sukayna al-Shihābī (Şam: Dârü'l-fikr, 1981), 33, 42, 43, 524.

30 Sehâvî, dindar kadınlar için tezevvecet ve tezevvecehe fiillerini kullanır: Sehâvî, Mu 'cemu'n-nisâ, 11 (Üns bint Abdülkerîm b. Ahmet isimli kadının biyografisinde); Sehâvî, Mu'cemu'n-nisâ, 16. Ancak, bazı durumlarda Sehâvî dindar kadınlar için de "taht” kelimesini kullanır. bk. Sehâvî, Mu 'cemu'n-nisâ, 20.

31 bk. Abdülkerîm el-Kuşeyrî, er-Risâle el-Kuşeyrîyye (Kahire: el-Bâbî el-Halabî, 1940), 203, str. 25-26. Eserin Türkçe tercümesi için bk. Abdülkerim Kuşeyrî, Tasavvuf İlmine Dair Kuşeyrî Risalesi, çev. Süleyman Uludağ (İstanbul: Dergah Yayınları, 1978). (çev. notu) 
Birkaç durumda, bazı evli kadınlar kendi seyr u sülûklerini sürdürürken belirli ölçüde bir özgürlük kazanmıştır. Sehâvî’nin (ö. 902/1497) Mu'cemu'n-nisảsında, Mekke'ye hac ziyaretini sadece kocasıyla değil, diğer birçok erkekle de beraber yapan bir kadından bahsedilir. Davranışını beğenmeyen kocası, sonunda kadından boşanmıştır. ${ }^{32}$ Bu hikâye tarihsel olarak doğru olmasa ve diğer sûfî yönelimli anekdotlarla birleştirilse bile, bu olay sûfî erkekler için oldukça "meydan okuyan” başka bir tür eşlik modelini ortaya çıkarabilir. Bu tip, Sülemî’nin ideal dindar kadın örnekleri arasında görünmeyen bir tiptir. Ahmed b. Hadraveyh'in (ö. 240/854-5) eşi Ümmü Ali Fâtıma'nın Bâyezîd-i Bistâmî’yle karşılaşmasını anlatan iyi bilinen bir hikâyenin Bâyezîd'in lehine yazılmış gibi görünen varyasyonunda, kadın eğer kocası onu yanındayken peçesini çıkarabileceği Bâyezîd'e götürürse, (boşandıkları takdirde) çeyizinin önemli bir kısmından kocasını muaf tutacağına söz vermiştir. Bir gün Bâyezîd, Fâtıma'nın elinin kınalandı̆̆ını fark ettiğinde artık görüşmelerinin mümkün olmadığına dair ek bilgi ise bu kaynakta yer almamaktadır. ${ }^{33}$ Isf̣ahânînin ilk metni bunu açıkça belirtmesine rağmen kanaatimce, Fâtıma'nın kocasını çeyizinden muaf tutma isteği, onun Bâyezîd ile evlenme niyetiyle ilgili değildi. ${ }^{34}$ Öyle olsun veya olmasın Fâtıma'nın davranışı, bazen kocalarının gurur ve özsaygıları pahasına olsa da sûfî kadınların zevk alabileceği bir bağımsızlık derecesini sembolize edebilir. Bu tür bir bağımsızlık kısmen, kadınların kendi zenginliğinden ve köklü maddi güçlerinden kaynaklanıyor gibi görünmektedir. Fâtıma ve kocası İbn Hadraveyh'in durumu buna bir örnektir. ${ }^{35}$

Sûfîler için bu tür evli kadınların oynadıkları "saf" ve "destekleyici” role dikkat çekilmesinin yanı sıra, evliliğin tehlikelerinin yinelenmesi göz ardı edilemez ve erken dönem

32 bk. Sehâvî, Mu'cemu'n-nisâ, 2.

33 bk. Sehlegî, en-Nûr min Kelimâti Ebîtt-Tayfûr, Şatahât es-sûfiyye, ed. Abdurrahman Bedevî (Kuveyt: Vekâlet elmatbuat, 1976), 170. Cornell, yanlıș bir șekilde bu varyasyonun İsf̣ahânî'nin Hilyetü'l-Evliyâ'sından kaynaklandığını belirtir. Bu bölüm, Hücvirî'nin Keşfu'l-Mahcûb'unda bulunur: (Hujwīrī, Kashf al-mahjūb, 120). Ayrıca bk. Ebû Nuaym el-İsfahânî, Hilyetü'l-evliyâ' ve tabakātü'l-asfiyâa', ed. Mustafa Abdülkâdir 'Atâ (Beyrut: Dârü'l-kütübi'lilmiyye, 1997), 10, 43; Farīd-al-Dīn 'Attar, Tadhkirat al-awliyā’, ed. R.A. Nicholson (Leiden: Brill, 1905), 1/288-289. Sülemî, tesadüfen bu hikayeden hiç bahsetmez (bk. Sulamī, Dhikr, 169). "Mehdi-i Aliya" soyadıyla da bilinen Ümmü Ali'yi anlatan kaynakların ayrıntılı bir araștırması için ayrıca bk. Richard Gramlich, Alte Vorbilder des Sufitums (Wiesbaden: Harrassowitz Verlag, 1996), 2 (İkinci Kısım: Doğunun Şeyhi), 99-102. Hilyetü’l-Evliyâ’nın Türkçe tercümesi için bk. Ebu Nuaym el-Isfahani, Hilyetu'l-Evliya, çev. Hüseyin Yıldız, Hasan Yıldız (İstanbul: Ocak Yayıncılık, 2015). Tezkiretü'l-Evliyâ'nın Türkçe tercümesi için bk. Feridüddin Attar, Evliya Tezkireleri, çev. Süleyman Uludă̆ (İstanbul: Kabalcı Yayınları, 2007). (çev. notu)

34 bk. İsfahânî, Hilyetü'l-evliyâ ', 10/43.

35 bk. Sulamī, Dhikr, 169. 
tasavvuf literatüründe "kötü” eşler genellikle Allah'ın sûfîlere cennetin lezzetlerini hatırlattığı "iyi”" ve "dindar" eşlerin övgüleriyle yan yana görülürdü. Tasavvuf dışı literatür, genellikle Tanrı'nın cezası ve lanetine dair keskin uyarılarla anılan "küstah" ve "ahlaksız" evli kadınlara atıflarla doludur. ${ }^{36}$ Sehâvî tarafından söz edilmeye değer görülen evli bir kadın, kocasından başka bir adama meyilliydi ve sonunda kocasını kendisinden uzaklaştırdı! ${ }^{37}$ Sehâvî’nin kitabındaki başka bir olayda, aynı zamanda vaiz ve oldukça iyi eğitimli bir kadın olan Bayram'ın evlendikten sonra "eşiyle ilişkisi nedeniyle statüsü değişir" (tegayyara hâluhâ bi-muhâlatâtihî). ${ }^{38}$ Yazar, bu ifadeye herhangi bir açıklama getirmese de evlilik sorumluluklarının bu kadını tam zamanlı-aktif bir şekilde çalışmaktan alıkoyması olasıdır. Sehâvînnin eseri hem kadınların hem de erkeklerin hayatları boyunca birden fazla evlilik yaptıkları izlenimini vermektedir. Bir kadın yaşamı boyunca birkaç kez evlenebilirken, erkekler aynı anda dört eşle evlenebilme ayrıcalığına sahipti. ${ }^{39}$ Kanaatimce bu durum, eşlerin birbirlerine duydukları bağımlılık ve bağllık hislerinin derecesini zayıflatmıştır. Bu nedenle iddiam, V./XI. ve VI./XII. yüzylllarda sûfî gruplarının ve pratiklerinin kurumsallaşma sürecinin, evlilik kurumundaki bağımlılığın normatif derecesinin daha da zayıflamasına katkıda bulunduğudur.

Teorik mükemmelliği, temelde Sühreverdînnin (ö. 632/1234) eseri Avârifü'l-Maârif ile ilişkilendirilen tasavvufî kurumsallaşmanın, sûfî takipçiler ve "yol"un sempatizanları arasında yeni sosyal kodlar yarattığı akılda tutulmalıdır. Sühreverdî’nin ayrıntılı talimatlarına göre sûfî grupların disiplinli üyeleri, zamanlarının çoğunu şeyhleri ve ihvanlarıyla birlikte geçirmeliydi. Mürşid terbiyesine (şeyhü’t-terbiye) duyulan temel ihtiyaç, müridi yerinden ayrılmak ve uygun bir mürşid aramak için tüm İslam topraklarında seyahat etmeye motive ederdi. ${ }^{40}$ Sühreverdî’nin eserine göre tasavvufî müesseseler takipçilerine, kendilerine izin verildiği ölçüde sosyal hayatlarını sürdürürken aynı zamanda sûfî topluluklarına bağlı kaldıkları, daha büyük bir özgürlük bahşetti.

36 bk. Nevevî, Riyâzü's-Sâlihîn, 92; Müttakī el-Hindî, Kenzü'l- 'ummâl fî süneni'l-akvâl ve'l-ef 'âl (Haydarâbâd-ed-Dukn: Dâirât el-Maârif el-Osmaniyye, 1974), 21/238-239. Ayrıca bk. el-Hindî, Kenzü'l- 'ummâl, 202-207.

37 Sehâvî, Mu 'cemu'n-nisâ, 64.

38 Sehâvî, Mu 'cemu'n-nisâ, 15 (Bayram bint Ahmed b. Muhammed'in biyografisinde).

39 bk. Yossef Rapoport, Marriage, Money and Divorce in Medieval Islamic Society (Cambridge: Cambridge University Press, 2005), 82-88.

40 Sühreverdî’nin yenilikçi sistemi için bk. Arin Salamah Qudsi, "Institutionalized Mashyakha in the Twelfth Century Sufism of 'Umar al-Suhrawardī”, Jerusalem Studies in Arabic and Islam 36 (2009), 381-424. 
Başka bir makalede, Sühreverdî’nin eşsiz doktrini “teşebbuh bi’s-sûfîyye” (sûfîleri taklit etme) ve onun tasavvufun teorik ve pratik sistemlerindeki başlica etkilerini incele$\operatorname{dim} .{ }^{41}$ [Buna göre] yolun nihai safhalarına ulaşıldı̆̆ında sûfîye, mübtediye yasaklanmış olan tüm davranış biçimleri için izin verilirdi. Bu uygulama, teorik tasavvufi sistemin erken dönemlerinden gelmesine rağmen, Sühreverdî ve çağdaşlarının öğretilerinin temel bir özelliği haline gelmiştir. Yine de bu öğretilerin çoğu hala evli kadınlara ve evliliğe karş1 şüpheli bir tutumun varlığına işaret etmektedir. Sühreverdî'nin bizzat kendisi, evli bir sûfînin yatakta bile "temiz" kalması ve "saf bir şekilde uyumak"la (nevm ale’t-tạhâra) şereflendirilmesi için eşine çok sık dokunmaması gerektiğini belirtir. ${ }^{22}$ Daha "hoşgörülü" bir bakış açısıyla, sûfî yaşantısının mümkün ve herkese hatta ara sıra hiçbir bağlılık olmaksızın sûfî ritüellerine katılmaya çalışanlara bile açık hale getirilmesine katkıda bulunan bu sistemin aslında eşlerin kocaları üzerindeki etkisini zayıflattığı ve eşlik kavramını (evli kadınlar adına) kötülediği kanaatindeyim. Suriyeli Râbia ve onun eşine olan maddi-manevi desteği hakkında anlatılan hikâyede olduğu gibi, dindar kadınlarla ilgili yukarıda bahsedilen kıssalar bunun delili olarak görülebilir. Râbia'nın sûfî eşi Ahmed b. Ebü'l-Havârî'yi desteklemesi, yalnızca bir eş olmasıyla değil, kendi manevi derecesi ve güçlü iç âlemiyle ilgili olmalidir.

Tasavvuf yolculuğu ve ailevi sorumluluklar arasındaki çatışmalar, erken dönem kaynaklarında iyice belgelenmiştir. Bir anekdota göre, Hasan-ı Basrî’nin oğlu babasının ihvanlarını istemezdi çünkü onlar uzun süre kalarak, onun dikkatini ailesinden ve çocuklarından uzaklaştırırdı. ${ }^{43}$ Çocuklarından biri öldüğünde yalnızca gülen sûfîlerle ilgili birçok "uç" hikâye ve Ruveym b. Ahmed (ö. 303/915) gibi kızına karşı nazik davranışlarını ihvan-

41 bk. Qudsi, “The Idea of Tashabbuh", 175-197.

42 bk. Şehâbeddin Sühreverdî, Avârifü'l-Maârif, (Ebû Hâmid el-Gazzâlî, İhyâü Ulûmi'd-dîn içinde) (Kahire: El-Bâbi elHalabî, 1967), 5/261. Bu eserlerin Türkçe tercümesi için bk. Şihâbüddin Sühreverdî, Gerçek Tasavvuf- Avarifü'lMearif, çev. Dilaver Selvi (İstanbul: Semerkand Yayınları, 2012); İmâm Gazâlî, İhyâu Ulûmi'd-dîn Tercümesi (İstanbul: Erkam Yayınları, 2019). (çev. notu)

43 Mekkî, Kūtü'l-kulûb, 2/455-456. 
larına açıklamak zorunda kalan "aile babaları" hakkındaki diğer hikayeler çoğunlukla bir tür edebi abartıdır. ${ }^{44}$ Aslında bekarlığı seçen sûfîler, istisnai bir gruptu.

İslam'a adanmışlık söz konusu olduğunda dindar kadın, bir anne ise çoğu kez güçlü maneviyatı ile ayırt edilirdi, hatta annelik görevleri onu Tanrı'ya ibadet etmekten alıkoyuyormuş gibi göründüğgünde [anne] kendini suçlardı. Nusiyye bint Salmân adında bir kadın doğum yaptığında üzülürken, ${ }^{45}$ Osmâne adında başka bir kadın, oğluna ibadet edip etmediğini sorduğu için kendisini suçlamış ve Tanrı'dan uzaklaşmıştır. ${ }^{46}$ Erkek sûfîlerin biyografilerinde anneleri genellikle bir zafer havasıyla tasvir edilmiştir. Burada, sûfî olmaları annelik görevleriyle çelişmediği gibi, sûfî oğullarına samimi ve sınırsız desteklerini de etkilememiştir. Bir sonraki bölümde, annelik ve tasavvufun bazı gizli yönlerini anlamak için bununla ilgili mevcut az sayıdaki veriden yararlanarak bir tasvir yapacağım. Derinlemesine araştııılması gereken asıl soru, yukarıda ifade edildiği şekliyle sûfî annelerin seyr u sülûk sürecinde oğullarına sunduğu "samimi" ve "sınırsız" destekle ilgilidir.

\section{Erkek Odaklı Biyografilerde Anneler}

Öyle görünüyor ki Sülemî dindar annelerden bahsettiği üç biyografide, anneleri "kutsal anne" imajına yaklaştıran destek veren kahramanlar olarak tasvir etmekle ilgilenmemiştir. Metinlerin edebi ve teorik yapılarına bakıldığında, annelik marjinal ve önemsiz görünmektedir. $\mathrm{Bu}$, dinleyicinin zaten tanıdığı birini, o kişinin aile ilişkilerinden bahsederek tanımlamak gibidir. Sülemî’nin eserinde, annelik bu kadınların dindarlıklarıyla ya da sûfî kimlikleriyle tamamen ilgisiz ve tesadüfi görünmektedir. Buna rağmen, yazarın neden anne rolleri ve desteği hakkında hiçbir şey söylemediğini sormak önemlidir. Sülemî, anne-

44 Ruveym'in hikayesi için bk. Ali b. Muhammed b. Hasan Deylemî, Sîret İbn Hafîf eş-Şirazî, çev. Yahya b. Cüneyd eşŞirazî- İbrahim ed-Desûkî Şatâ (Kahire: Mecmu' el-buhûs el-İslâmiyye, 1977), 152. Müslüman dindarlığılla ilgili erken dönem yazılarında, yazarlar sıkça bir babanın eşlerine ve çocuklarına karşı ilgisizliğini överken, ihvanlarına yönelik sempatisini ise bazen kişinin ailesine yönelik sempatisine tercih ederler. Örnekler için bk. Kuşeyrî, Risâle, 84, str. 29-30; 10, str. 5-7. Zühd kaynaklarındaki örnekler için bk. Muâfâ b. İmrân, Kitâbü'z-Zühd, ed. Âmir Sabrî (Beyrut: Dârü'l-Beşâirü'l-İslâmiyye, 1999), 186, No. 14; 188, No. 19; 192, No. 25. Örneğin Mekkî, kişinin çocuklarını "dini hukukta yer alan meșru amellere olan arzusunun ilahi cezası" (ukûbat şehvetu'l-helal) olarak tanımlar (Mekkî, Kūtü'l-kulûb, 2/491). Ebû Nuaym el-İsfahânî, Süfyân es-Sevrî̀nin (ö. 161/777) eşi, ona oğlunu gönderdiğinde, oğlunu kucağına oturtup "Keşke cenaze törenine davet edilseydim” dediğini aktarır. (İsfahânî, Hilyetü'l-evliyâ', 7/78-79). Sûfînin, ihvanlarını ailesine tercih etmesi üzerine örnekler için bk. Ebû Abdirrahmân esSülemî, Kitâbü'l-Erbaîn fït-Tasavvuf (Haydarâbâd: Meclis Dâirât el-Maârif el-Osmaniyye, 1950), 11; Mekkî, Kūtü'lkulûb, 2/ 455-456; Sühreverdî, Avârif, 253.

45 Sulamī, Dhikr, 93. Eşleri ve çocukları öldüğünde Tanrı'ya şükreden Hristiyan kadın mistikler hakkında benzer hikâyeler için bk. Herlihy, Medieval Households, 115; not 12, 208). Bununla birlikte, bu hıristiyanî benzerliklerin bazılarında, bu tutum kocaların veya diğer yakın akrabaların dahil olduğu zalim bir muamelenin yașandığı sefil aile hayatına bir tepki gibi görünüyor. (bk. Herlihy, Medieval Households, 115). 
leri tamamen ihmal etmiş görünürken, eşlerin ve kız kardeşlerin desteğini anlatmaya neden bu kadar hevesliydi? Yazarın, sûfî oğluna destek veren maneviyatı güçlü, seçkin bir kadın tanımadığını ileri sürmek mümkün olabilir mi? Ebû Abdullah el-Rûzbârînnin (ö. 367/977) annesi Fâtıma b. Ahmed'in biyografisinde, oğlu için "o bir sûfî değil ancak salih bir adam (racul sâlih)”, kardeşi içinse “ama kardeşim Ebû Ali gerçek bir sûfîdir” dediği aktarılır. ${ }^{47}$ Bu bilgileri göz önünde bulundurarak, sûfî annelerin aslında oğulları için güçlü bir destek ve "saf" bir manevi motivasyon olmadığı aksine Tanrı'ya ulaşmaya çalışan oğullarının yolunda güçlü bir engel olduğu sonucuna varabilir miyiz?

Attar'in Bâyezîd-i Bistâmî biyografisinde, Bâyezîd'in annesi menaviyatı güçlü bir kadın olarak tasvir edilmiştir. Bâyezîd, mürşidinin Kur'an ayeti için yaptığı "Bana ve anne babana şükret"48 şeklindeki açıklamasını duyduğunda, annesine şunları söylemek için evine gitmiştir: "men der dû hâne kuzekhuza'în netevânem kerd" (aynı anda iki evde yönetici olamam). Buradan kasıt, annesinin oğlunu ya tamamen kendisine adamasına izin vermesi için Tanrı'ya yakarması ya da onu bütünüyle Tanrı'ya adamasıdır. Attar, Bâyezîd'in annesinin “git ve Tanrı'nın ol” diyerek, onu kendisine karşı görevlerinden muaf tuttuğunu aktarır. ${ }^{49}$ Bâyezîd'in annesinin bu seçkin imajı, erken dönem tasavvuf literatüründe iyi işlenmiş görünmektedir. Kuşeyrî Risâlesỉnde Bâyezîd, annesinin kendisine hamileyken, temiz olmama şüphesi taşıyan yiyeceklerden kaçınmayı küçümsemesi ile anılır. ${ }^{50}$ Sehlegî’nin en-Nûr min Kelimâti Ebi't-Tayfûr unda ilgili birkaç anekdot gündeme getirilmiştir. ${ }^{51}$ Bir anekdota göre bu kadın "hemcinsleri arasında benzersizdi" [...]. Bir keresinde oğlunun [manevi] rahatsızlığını fark ettiğinde şöyle demiştir: "Sakin ol!" Bâyezîd, bu ifadenin kendisini sarhoş ettiğini söyler ve sonuç olarak, onun yoğun iç karışıklığı geçer. ${ }^{52}$ Bâyezîd'in babasının, ailesinin evinde yediği şüpheli yiyeceklerin midesinden tamamen boşaldığından emin olmak için, eşiyle cinsel ilişkiye girmeden önce kırk gün beklediği belirtilir. ${ }^{53} \mathrm{Bu}$ tür anekdotların, destekleyici figürler olarak sûfî annelerin kurgusal imajlarını tamamlamaya katkıda

47 Sulamī, Dhikr, 214.

48 'Attar, Tadhkirat al-awliyā', 1/136. İngilizce tercüme, Arberry'nin Attar'ın çalışmasından seçtiği bölümlerle oluşturduğu şu esere dayanmaktadır: 'Attar, Muslim Saints and Mystics: Episodes from the Tadhkirat al-awliyā' (Evliyâa Tezkireleri), çev. A.J. Arberry (London: Routledge \& Kegan Paul, 1966), 102.

49 'Attar, Tadhkirat al-awliyā', 136; 'Attar, Muslim Saints, 102.

50 Kușeyrî, Risâle, 119, str. 22-23; Mevsılî, Menâkıbü'l-ebrâr, 1/193; Sehlegî, Nûr, 179.

51 bk. Sehlegî, Nūr, 92-93.

52 Sehlegî, Nūr, 62.

53 Sehlegî, Nūr. 
bulunduğu ve özellikle Bâyezîd ve diğer erkek sûfilerin manevi tasvirlerine başka bir boyut eklemek için tasarlandıkları açıtır. Bu hikayelerin tarihsel boyutunu göz önüne alamasak da Bâyezîd'in annesinin gerçekten seçkin bir kadın olduğunu ve tasavvuf literatüründe kısaca belirtilse de onun oğluna verdiği manevi desteğin, karakterine olan benzersiz ilgiyi haklı çıkardı̆̆ını varsaymak muhtemel görünüyor.

Açıkça, tanınmış şeyh Ebû Abdullah ibn Hafîf eş-Şîrazînin (ö. 371/981) annesi Ümmü Muhammed, tasavvuf tarihindeki en ünlü anne gibi görünüyor. Deylemî, Sîretü's-şeyhi'lkebîr adlı eserinde bu kadının, oğlu yokken zaman zaman şeyh efendileri evine davet ettiğini aktarmaktadır. ${ }^{54}$ Ümmü Muhammed'in hac sırasında oğluna eşlik ettiği de belirtilmiştir. ${ }^{55}$ İbn Hafîf, çabuk öfkelenen ve huysuz tabiatlı Ebû Amr ez-Zeccâcî (ö. 348/959) ile karşılaştığı son Mekke ziyaretinde annesini de yanında götürmüştür. Görüşmeleri sırasında Zeccâcî, İbn Hafîfe sorar: "Bu dünyada herhangi bir şeye sahip misin?" Şirazlı ziyaretçi cevap verir: "Ah şeyhim, velilerin nitelikleri tartışlırken, dünyevi işler hatırlanamaz!" Muhtemelen, İbn Hafîf in annesinin halen dahi oğlu üzerinde güçlü bir etkiye sahip olduğu fikrinden rahatsız olan Zeccâcî şunları söylemiştir: "Sahip olduğun her şeyi annen adına mı aktardın?" (rubbemâ ce'elte mâ temlik bi-ism ummik). Bu açıklama, erken dönem sûfî idealinin açık bir yansıması olan "gerçek sûfînin hiçbir şeye sahip olmadığı ve hiçbir şey tarafından sahip olunmadığı" (es-sûfî lâ yemliku şey'en ve-lâ yemlikuhu şey’) ifadesini içerir. ${ }^{56} \mathrm{O}$ halde Zeccâcînnin, "dünyevi” bağlarının ve aile ilişkilerinin tasavvuf yolculuğunu etkilemesine izin verdiği için dolaylı olarak İbn Hafîf'i suçladığını öne sürmek mümkün olabilir mi? Erken dönem sûfîleri için seyahat manevi yükselişin içsel rotasına eşdeğer olduğundan, memleket veya ülke ile duygusal ve maddi bağlardan kaçınmak iyi bilinen bir ilkeydi. ${ }^{57}$ Bir Farsça ifade şöyle der: "Bugün Bağdat, her yönden Buhara'dır." ${ }^{58}$ [Bunun üze-

54 bk. Deylemî, Sîret, 266.

55 bk. Sehlegî, Nūr, 141.

56 Kuşeyrî, Risâle, 139, str. 8-9. bk. Najm al-Dīn Kubrā, Fawā' ’ih al-jamāl wa-fawātih al-jalāl, ed. Fritz Meier (Wiesbaden: Franz Steiner Verlag, 1957), 45.

57 Örnekler için bk. Sarrāj, Luma ', 189, str. 8. (haysume vekafe kalbuhu yekûnu menziluhu); Kuşeyrî, Risâle, 143, str. 9-14; İzzeddin Mahmud Kâşânî, Misbâh el-hidâye ve-miftâh el-kifâye, ed. Celâleddin Humâyî (Tahran: Müessese-i Naşrihumâ, 2002), 263. bk. Tasavvuf literatüründe sonraki ideal, asıl hedefin evrende yolculuk etmek yerine sûfinin kendi içine yolculuk etmesi olduğudur. Bu teori üzerine bk. Hellmut Ritter, The Ocean of the Soul: Man, the World and God in the Stories of Farìd al-Din 'Attar, çev. Bernd Radtke-John O'Kane (Leiden and Boston: Brill, 2003), 637.

58 Mohammad Ebn-e Monavvar, The Secrets of God's Mystical Oneness or The Spiritual Stations of Sheikh Abu Sa'id [Esrârü't-tevhid fi makâmâtü'ş-Şeyh Ebû Saîd], çev. John O'Kane (Costa Mesa, CA \& New York: Mazda Publishers, 1992), 104. Bu eserin Türkçe tercümesi için bk. Muhammed İbn Münevver, Tevhidin Strları, çev. Süleyman Uludağ (İstanbul: Kabalcı Yayınevi, 2004). (çev. notu) 
rine], İbn Hafîf in Zeccâcîye beklenmedik cevabı ise şuydu: "Ey şeyhim, Allah adamlarından (ricâlullah) bahsedildiğinde, kadınlardan bahsetmeye değmez!"59 Sonuç olarak, Zeccâcî, İbn Hafîfe hayran kalmış, onu yemeye davet etmiş ve ondan annesine biraz yemek götürmesini istemiştir. ${ }^{60}$ Kanaatimce İbn Hafîf in cevabı, onun asıl duruşunun bir ifadesinden ziyade Zeccâcînin bakış açısı üzerine inşa edilen tartışmanın gerekli bir sonucuydu.

Ümmü Muhammed'in yukarıda bahsedilen etkisi, başka bir hikâyede açıkça ortaya konmuştur; buna göre Ebû'l-Abbâs ibn Atâ, başka bir hırka giydirmek amacıyla İbn Hafîf'in hırkasını çıkarmak istediğinde İbn Hafîf ona izin vermemiştir çünkü "ona bu hırkayı giydiren annesiydi ve onun dışında kimsenin hırkayı çıkarmasına izin verilmezdi." ${ }^{" 1}$ Kuşeyrî Risâlesi'nin bir bölümünde, İbn Hafîf annesinden seyahat izni ister ve [bunu anlatmak amacılla] yamalı cüppesini sorması için birini annesine gönderir. Annesi "fe-lem tu'âridnî el-vâlide ve-radiyat bi-hurûci" diyerek yolculuk isteğini kabul eder. ${ }^{62}$ Bu söz, Ümmü Muhammed'in sıradan bir şeyh annesinden daha fazlası olduğu izlenimi uyandırmaktadır. İbn Hafîf, hayli tanınmış ve saygın biri olmasına rağmen, bilge bir kadın olan annesine bağlı kalmış ve kendi kararlarını verme hususunda her zaman bütünüyle özgür hissetmemiştir. En azından seyahat konusunda annesine bu tür bir bağlllığı sürdürdüğünü biliyoruz. Başka bir anekdota göre İbn Hafîf, Ramazan'ın son on gecesinden birine denk gelen Kadir gecesinde evinde çokça ibadet ederek ilahi bilgiye ulaşmaya çabalarken, bu bilgi annesine zahmetsizce bahşedilmiştir. Annesi, ilahi nuru kendisiyle paylaşması için "Ah oğlum Muhammed! İşte aradığın şey” diyerek oğlunu çağırmıştır. İbn Hafiff aceleyle annesinin yanına gitmiş, onun ayaklarına kapanmış ve onu çevreleyen nurun bir kısmını nasiplenmiştir. ${ }^{63} \mathrm{Da}-$ ha sonra da şöyle demiştir: "Şimdi bir annenin değerini anlıyorum." ${ }^{64}$

Ebû Saîd-i Ebû-l-Hayr'ın (ö. 441/1049) torunu Muhammed b. Münevver, Esrârü'tTevhîd fî Makâmâti'ş-Şeyh Ebû Saîd isimli biyografisinin başında, dedesinin annesinden bahseder. Bir gece, Ebû Saîd'in babası dervişlerin sohbetine gitmeyi planladığında, şeyhin

60 Deylemî, Sîret, 142.

61 bk. Deylemî, Sîret, 159.

62 Kuşeyrî, Risâle, 145, str. 21.

63 bk. Muînüddîn Cüneyd Şîrâzî, Şeddü'l-izâr fî hațți'l-evzâr 'an züvvâri'l-mezâr, ed. Muhammed Kazvînî-Abbas İkbâl (Tahran: Çaphâne-i Meclis, 1949), 368; Deylemî, Sîret, 250.

64 Şîrâzî, Ședdü'l-izâr, 369. 
annesi ondan şunları istemiştir: "Ebû Saîd'i yanınıza alın ki dervişlerin ve maneviyatı güçlü adamların bakışları ona değebilsin.”65

Ebû Saîl'in babası sûfîlerin sohbetlerine/faaliyetlerine yoğun bir şekilde katılmasına rağmen, muhtemelen küçük oğlunun bu sohbetlere katılacak kadar olgun olduğuna inanmamıştır. Diğer taraftan annesi ise tasavvuf geleneğine göre ilahi bilgiyi engelleyen ve kalbin saflığını karartan entelektüel yetilerini kazanmadan önce dindar dervişlere eşlik etmenin çocuğunun düşünceleri/zihni üzerindeki etkisini fark etmiş görünmektedir. Ebû Saîd'in annesi ve babası öldüğünde, yazar şöyle der: "Ebeveynlerini gözetmeye dayalı kısıtlamalar yolundan kaldırıldı."66 Sonrasında, Ebû Saîd çöle doğru yola çıabilmiş ve yedi yıl boyunca münzevi ${ }^{67}$ şekilde ağır riyazetler uygulamıștır. Sûfî tabakatlarında sık sık hakku'lvâlide (anne hakkı) kavramıyla karşılaşırız. ${ }^{68}$ Her durumda, bu kavram sûfînin seyahat etme ve maneviyatını geliştirme ihtiyacını göz önünde bulundururken hesaba katması gereken ailevi kısıtlamalara işaret eder. Bazı örneklerde, Mekke'ye hac yolculuğu yapmak sûfînin kendi ebeveynlerine karşı görevleriyle çelişirdi. Bu nedenle birçok şeyh, müridlerine anne babaları hayatta olduğu sürece, hacca gitmek ya da başka herhangi bir nedenle seyahat etmek yerine ebeveynlerine "hizmet etmelerini" emretmiştir. Ebû Saîd'in biyografisine dönecek olursak, onun her zaman dağlarda ve çölde dolaştığı, babası sonunda onu bulup eve getirene kadar günlerce hatta aylarca kaybolduğu bilgisi ile karşılaşırız. Ebû Saîd, ebeveynlerini memnun etmek için bazen gezintilerinden ve riyazetlerinden vazgeçerek eve gelmeyi kabul ederdi: "Şeyhin babası sürekli onu arar ve neredeyse her ay bulup zorla Meyhene'ye ${ }^{69}$ geri getirirdi ki [. . .] tekrar kaçmasın."70 Attâr'ın Tezkire'sinde Bâyezîd'in annesine atfedilen ("git ve Tanrı'nın ol") ifadesinin aksi bir olay Ebû Saîd [için aktarılır], Ebû Saîd, evinin önünde otururken, annesi kapiya gelir ve der: "Içeri gel! İçeri gelmelisin." Ebû Saîd, içeri girmez ve kendi evini terk eder. ${ }^{71}$ Burada, sûfî annelerinin yüzleşmek zorunda kaldığı ciddi zorluk söz konusudur. Ebû Saîd'in annesinin ifade ettiği şek-

65 Ebn-e Monavvar, Esrârü't-Tevhîd, 76.

66 Ebn-e Monavvar, Esrârü't-Tevhîd, 105.

67 Tercümede münzevi olarak ifade ettiğimiz kavram metinde "ascetic" olarak geçmektedir. Bu kelime, tercümede bağlama göre münzevi veya zühdi şeklinde kullanılmıştır. Müellifin, metinde ascetic ve zuhdi kavramlarını birbirinin yerine kullandığına dikkat çekmemiz gerekir. Buna mukabil, bu iki kavram arasındaki farka yer veren bir çalışma için bk. Leah Kinberg, “What is Meant by Zuhd?”, Studia Islamica 61 (1985), 27-44. (çev. notu)

68 bk. Hujwīrī, Kashf al-mahjūb, 91; Câmî, Nefehâtü'l-üns, 191, 322.

69 Meyhene (Mehne), Ebû Said'in doğduğu kasabadır. (çev. notu)

70 Ebn-e Monavvar, Esrârü't-Tevhid, 93. Bir sonraki alıntı için bk. Ebn-e Monavvar, Esrârü't-Tevhid, 96.

71 Ebn-e Monavvar, Esrârü't-Tevhid, 95. 
liyle "mürşidlerin bakışının lütfu", bir annenin çocuğunu tasavvuf yoluna girme konusunda motive etmesinin hakiki göstergesi olarak "ciddiyetle" kabul edilmemiștir. Onlar için özellikle de haleflerinin uygulamalarıyla çoğunlukla tezat şekilde hakiki yoksulluk ve inziva ideali olan erken dönem sûfîleri için- tasavvuf yoluna giriş, büyük olasılıkla kişiyi aşırı münzevi yaşama ve ağır riyazetlere maruz bırakmıştır. Bu sebeple de anneler böyle bir zorlukla yüzleşmeye istekli davranmamıştır. Bâyezîd'in annesine atfedilen "Kapıyı yarı açık bırak!" sözü, bazı sûfî annelerinin çocuklarının sosyal bağlarından vazgeçip tüm hayatlarını seyr u sülûke adadıklarını izlerken baş etmek zorunda kaldıkları derin duygusal krizi ima etmiş olabilir. Bu bağlamda, "yarı açık kapı", annelerin çocukları ile güçlü bir ilişki sürdürme çabalarını ve çocuklarının onlara karşı hissettiği güçlü bağımlılığı sembolize eder. Hadis literatüründe geçen Hıristiyan Aziz Cüreyc'in meşhur hikayesi ve annesiyle olan ilişkisi bunun bir başka delilidir. ${ }^{72}$ Hikâyenin bir varyasyonuna göre, Cüreyc'in annesi ibadet ritüelinin ortasındayken onu çağırır. Cüreyc, çağrıya cevap vermeyince, tekrar tekrar bağırır. [Ve sonunda] Cüreyc, itaatsizliğinin cezası olarak zina ile suçlanır. ${ }^{73} \mathrm{Bu}$ ister anneye hürmet göstermenin dini vecibeleri yerine getirmekten daha üstün olduğunu vurgulamak için kurgusal bir hikâye, ister otantik bir olay olsun, bu ve benzeri hikayeler şüphesiz annelerin gerçekte nasıl davranabileceğini gösteren kaynaklara dayanmaktadır. ${ }^{74}$

Bouhdiba'nın yukarıda bahsedilen müslüman annelerle ilgili makalesinde sıklıkla kullandığı genelleyici ve bazen de biraz keyfi üsluba katılmıyorum. Bununla birlikte, anneçocuk ilişkisinin müslüman toplumlarda kadın-eş (wife) ve karı-koca ilişkileri üzerindeki [etkisini anlamak için] yazarın bu ilişki türünün erdemlerinden bahsettiği kapsamlı çalışmasından yararlanmak oldukça önemli görünmektedir. Bouhdiba, "bu nedenle çocuklar çoğu zaman istikrarın tek faktörünü oluştururlar. Sadece onlar sıla-i rahime gerçek anlamını ve değerini verir- özellikle çocukların velayeti neredeyse her zaman anneye verilir",

72 Bununla ilgili olarak bk. J. Horovitz, “Djuraydj”, EI2, 2/602.

73 bk. Kuşeyrî, Risâle, 176, str. 28-36. Bu hikaye başka bir yerde, ebeveyne saygının ibadet ritüellerinden daha önemli olduğunu örneklemek için anlatılır. (bk. İbnü'l-Esîr el-Cezerî, Üsdü'l-gābe fî ma 'rifeti's-sahâbe, ed. Muhammed el-Bennâ vd (b.y: y.y, 1970), 5/53. bk. Sehlegî, Nūr, 92; Mekkî, Kūtü'l-kulûb, 2/579.

$74 \mathrm{Bu}$, David Herlihy'nin Orta Çă̆'ın sonlarında yaşayan hıristiyan azizlerin yaşamlarına ilişkin dile getirdiği bir noktaydı. Yazar şöyle aktarır: "Demek istediğim, yaşamların içerdiği annelik, çocukluk ve babalık çağrışımlarının, annelerin, çocukların ve babaların gerçek dünyada görülme biçimleriyle birtakım benzerlikler taşıması gerektiğidir. Bu imgeler, okuyucu veya dinleyici tarafında duygusal bir tepki uyandırmak için tasarlanmıștır; adanmışlık bağlamında ifade edilen duygular, hakkında hiçbir kayda sahip olmadığımız sıradan ailede hakim olan duygularla paralellik göstermiş olmalıdır". (Herlihy, Medieval Households, 115). 
der. ${ }^{75}$ Yazar, ayrıca "bu kadar çok sayıda müslüman annenin neden istismarcı görünecek kadar sahiplenici olduğunu" anlamaya çalışırken, "müslüman annelerin" "çileyle" ve "sabırla" geçen uzun tarihine atıfta bulunmaktadır. Ona göre bu dinamik, annenin "tüm sevgi ve şefkatini çocuklarına aktarmasına" yol açmaktadır. ${ }^{76}$ Bouhdiba'nın İslami bağlamda "annelerimizin gölgesinde" istismar ve hapis şeklinde ele aldığı anne-çocuk ilişkisinin psikolojik analizi, bu anne imajına saldırmak ve kendi kanatlarımızla uçmak için onlara duyulan aşırı ve patolojik saygıdan kurtulmak amacıyla çağrıda bulunmak için tasarlanmıştır.77

Sıla-i rahim kavramı, İslam'da önemli bir yere sahiptir. En ünlüleri İbnü'l-Cevzî ve Muhammed b. el-Velîd et-Târtûş̂̀ye (ö. 519/1126) ait olan "birru'l-vâlideyn" (ebeveyne saygı) şeklinde isimlendirilen birkaç eser mevcuttur. ${ }^{78} \mathrm{Bu}$ amaca hizmet eden birçok hadis de vardır, bunlardan meşhur bir tanesi birinin Hz. Peygamber'e sorduğu şu sorudur: "Kime saygı duymalıyım?" Hz. Peygamber, "annen" diyerek üç kez tekrarlar ve "sonra, babana [saygı göster!]", der. ${ }^{79}$ Gazzâlî, anneye olan doğal ihtiyacın babaya göre önceliğini açıladığını ve bu nedenle çocuklardan annelerine karşı babalarına kıyasla iki kat daha fazla sorumluluk sahibi olmalarının talep edildiğini belirtir. ${ }^{80}$ Tasavvufi bağlamda, annelere karşı sorumluluk sadece İslam hukuku ve sünnete uymanın bir beyanı değil, daha ziyade kapsamlı bir öz disiplin (mücahede) ve riyazet sisteminin bir parçasıdır. Ebû Nu'aym elİsfahânî’nin yer verdiği sûfî biyografilerinden biri, annesine karşı eşsiz sorumluluk duygusu nedeniyle övülen Ebû Abdullah Kahmas ibn el-Hasan adında dindar bir adama adanmıştır. Bir keresinde bir grup arkadaşı evinde onu ziyarete gelmiş, bu insanlardan hoşlanmayan annesi, oğlundan onlarla arkadaşlık etmemesini talep etmiş ve bu nedenle o da onlardan bir daha evine gelmemelerini istemiştir.81 Kahmas, annesine olan içten bağlllı̆̆ nedeniyle hacca gitmemiş, annesi öldükten sonra Mekke'ye gitmiş ve hayatının geri kala-

75 Bouhdiba, "In the Kingdom of the Mothers", 215.

76 Bouhdiba, "In the Kingdom of the Mothers".

77 Buhdiba, "In the Kingdom of the Mothers", 227.

78 Ebü'l-Ferec Abdurrahmân İbnü'l-Cevzî, Birru'l-vâlideyn, ed. Muhammed Abdülkâdir Atâ (Beyrut: Müessese elKütübi's-Sekâfiyye, 1988); Ebûbekir Muhammed b. El-Velîd et-Tartûsî, Birru'l-vâlideyn: mâ yecib alâ'l-vâlid liveledihi ve-mâ yecib alâ'l-veled li-vâlidihi, ed. Muhammed Abdülkerîm el-Kâdı (Beyrut: Müessese el-Kütübi'sSekâfiyye, 1986).

79 Muhammed b. İsâ et-Tirmizî, el-Câmi el-kebîr, ed. Başşâr Ma rûf (Beyrut: Dârü'l-garb el-İslâmi, 1998), 3/463; Nevevî, Riyâzü's-Sâlihîn, 99.

80 Ebû Hâmid Muhammed el-Gazzâlî, İhyâü Ulûmi'd-dîn (Kahire: Dârü'l-Menâr, ts.), 2/323.

81 İsfahânî, Hilyetü'l-Evliyâ, 6/230. 
nını orada geçirmiştir. ${ }^{82}$ Benzer anekdotlar, İbnü'l-Cevzî'nin, Târtuşî'nin ve diğer birçoklarının yukarıda bahsedilen eserlerinde bulunur. ${ }^{83}$ Bununla birlikte, İslam toplumunda ebeveyne saygısızlık hususunda "daha az ideal” vakalara da rastlanabilir. İbnü'l-Cevzî, kısa risalesinin girişinde, yaşamı boyunca şahit olduklarını dile getirir: Pek çok genç erkek, ebeveyne saygı duymayı dini bir görev olarak görmez [. . .] ve "rahim bağlarını" (yakta'ûn el-erhâm) yok sayar. ${ }^{84}$ İbnü'l-Cevzî tarafından anlatılan anekdotlar, ebeveynlerine itaatsizlik edenleri bekleyen kötü kaderin delillerini sunmasına rağmen, daha sonra tanınmış sûfîler haline gelenlerin çoğu, ebeveyn saygısının "geleneksel” imgesi olmaktan çok uzaktı. Bu tür anekdotların tam olarak tarihsel olmadıklarını düşünsek bile, ebeveyne saygının her zaman görülmediğini yansıttıkları ortadadır. ${ }^{85}$ Bundan dolayı, İslam ve hatta tasavvuf eserlerinde yer alan bu saf din ahlakı imgesindeki ısrar, mutlak ebeveyn saygisının otomatik olarak müslüman yaşamının bir parçası olarak görülmediğini ima edebilir. Bazen çocuk -anne ilişkisi sûfî-Tanrı ilişkisiyle ya da V./XI. yüzyılı takip eden geç klasik dönemdeki mürid-mürşid ilişkisi ile karşılaştırılır. İyi bilinen bir hadise göre, genellikle hac ve onun saflığı ve günahtan vazgeçmeyi sağlayan temel unsurlarıyla ilgili görülen ve kişinin saflığıyla iffetini yeniden doğduğu güne (racea' ke-yevm veledethu ümmühü) dönerek tanımlayan İslami ifade, tasavvuf literatüründe ayrı bir önem kazanmıştır. ${ }^{86}$ Sûfî yazarlar, tevbenin ve abdest ve ibadetleri yerine getirmenin manevi etkilerine ilişkin tartışmalarında bu ifadeden sık sık yararlanmıştır. ${ }^{87}$ Diğer durumlarda, ana rahminden çıkış, "dünyanın ruhuna yas tutmak" için ortaya çıkma (el-hurûc mine'l-gam ilâ rûhi'd-dünya) fikriyle karşılaştırılır. ${ }^{88}$ Tüm bu bağlamlarda, çocuk-anne ilişkisinin en başı, sürekli ahlaksızlık yapan ve günah işleyen bedendeki ruhun süreksiz yaşamını anlatan tavrü'l-hilkanın (yaratma aşaması) aksine, insanoğlunun fiili doğumundan önceki manevi aşamayı yaratıkların bedensel olarak doğmadıkları aşama- anlatan tavrü’l-fitrayı (doğuştan gelen

82 bk. İsfahânî, Hilyetü'l-Evliyâ, 229; Ebü'l-Ferec Abdurrahmân İbnü'l-Cevzî, Sıfatü's-safve, (Haydarâbâd: Meclis Dâirât el-Maârif el-Osmaniyye, 1968-1972), 3/234.

83 Oğullarına eşlerinden boşanma emri veren annelerde durum böyledir. bk. Ebü'l-Ferec Abdurrahmân İbnü'lCevzî, Ahbâru'n-nisâ (yanlışlıkla İbn Kayyım el-Cevzî̀ye atfedilmiştir), ed. Ahmed b. Ali, (Kahire: Dârü'l-Menâr, 1998), 55-56; Nevevî, Riyâzzü’s-Sâlihîn, 102; Tirmizî, el-Câmi el-kebîr, 3/ 465-466.

84 İbnü'l-Cevzî, Birru'l-vâlideyn, yazarın giriș bölümü, 25 .

85 Sarhoşken annesini öldüren Muhammed b. Harun'un hikayesi için bk. İbnü'l-Cevzî, Birru'l-vâlideyn, 65.

86 bk. Muhammad b. İsmâil el-Buhârî, Sahîh el-Buhârî (Beyrut: Dârü'l-kütübi'l-ilmiyye, 2001), 282 (no. 1521); Muhammed b. Ahmed el-Kurtubî, el-Câmi li-ahkâm el-Kur'ân (Beyrut: Dârü'l-fikr, 1993), 1/378.

87 bk. Gazzâlî, İhyâ, 1/237, 284.

88 İsfahânî, Hilyetü'l-Evliyâ, 7/25. 
aşama) ifade eder. Kuşeyrî, mütevekkilin (Allah'a mutlak güven duyan) bir tanımından alıntı yaparak şöyle yazar: "Mütevekkil, annesinin memesi dışında başka bir sığınak tanımayan yeni doğmuş bebek gibi Allah'tan başka hiç kimse tarafından yönlendirilmez."89 Mecdüddin el-Bağdâdî (ö. 607/1210 veya 616/1219), mürşid ile müridi arasındaki eşsiz manevi ilişkiyi "köleliğin embriyosu" (cenîn el-ubûdiyye), sûfînin müridliğini (iradesini) içinde bu "embriyonun" yaratıldığ "rahim", mürşidi ise süt anne (zi'r) olarak bu müridi eğiten ve ruhen emziren kişi şeklinde tanımlar. ${ }^{90}$ Mürid-mürşid ilişkisi bağlamında görülen müridin bakışının mürşidi üzerindeki derin etkisi, benzer şekilde anne hürmeti ve çocuğun ona bakışının etkisine atıfta bulunan ebeveyne saygı bağlamında da gözlemlenir. ${ }^{91}$

Diğer durumlarda anneler, sûfîye rehberlik etmesi için Tanrı tarafından yönlendirilen ve sûfînin önündeki bazı gayb perdelerini ortadan kaldıran kahraman vizyonerler olarak tasvir edilir. ${ }^{92}$ Hippolu Augustine, otobiyografik itirafları Confessions'ta, hıristiyan annesi Monica'yı Tanrı'ya ait sözler ve davranışlarla kendisinin önünde tezahür eden bir araç olarak tasvir eder. [Annesinin] oğlu için öngördüğü manevi yaşam düşüncesiyle, ${ }^{93}$ kendi hayatı da, oğlunun deneyimlediklerine paralel şekilde yoğun bir ruhsal dönüşüm göstermiş, "alkol zafiyetiyle" geçen uzun bir dönemden sonra [Monica da] derin bir hıristiyan inancına yönlendirilmiştir. ${ }^{94}$ Otobiyografisinde, annesinin ölümünden bahseden Augustine, Monica'nın ona sadece dünyevi varlığını bahşetmekle kalmadığını, onun sayesinde "sonsuzluğun ışığına" da doğduğunu aktarır..$^{95}$ Yeni veya ikinci bir yeniden doğuşun sembolü, bir müridin zorlu eğitim süreciyle mürşidinden yeniden doğduğu fikrini ifade etmek için insanın ruhen yeniden doğduğu şeklindeki kadim dini anlayıştan yararlanan daha sonraki sûfîler tarafından güçlü bir şekilde vurgulanmıştır. ${ }^{96}$ Mürşidi babaya benzetmek, şu şekilde ifade edilebilir: "Oğul doğal doğumda babasının bir parçası olduğu gibi mürid de manevi doğumda mürşidinin bir parçasıdır".97 Kanaatimce bu, kadim uygarlıklarda

89 Kuşeyrî, Risâle, 85, str. 20-21.

90 bk. Najm-al-Dīn Kubrā, Fawāih, 279 (Necmeddîn el-Bağdâdî, Tuhfetü'l-berere).

91 bk. İbnü'l-Cevzî, Birru'l-vâlideyn, 41, 47, 49.

92 bk. Ebûbekir Abdullah b. Muhammed el-Mâlikî, Riyâdü'n-nufûs fi Tabakât Ulemâi'l-Kayruvan ve Ifrikiyye ve Zühhâdihim ve-Nussâkihim ve-Siyer min Ahbârihim ve-fedâilihim ve-evsâfihim. ed. Başîr el-Bakkûş (Beyrut: Dârü'l-garb elİslâmi, 1983), 1/255.

93 bk. Saint Augustine, Confessions, çev. Henry Chadwick (Oxford: Oxford University Press, 1998), 49, 88, 108.

94 bk. Saint Augustine, Confessions, 167.

95 Saint Augustine, Confessions, 166.

96 Manevi yeniden doğuş (el-vilâde er-rûhiyye/ el-ma’neviyye) kavramını işlediğim çalışma için bk.: Salamah Qudsi, "Institutionalized Mashyakha", 390-393.

97 Sühreverdî, Avârifü'l-Maârif, 104. 
“Tanrı'nın annesi” ifadesiyle açıkça temsil edilen maneviyat ve kutsallaştırma üzerine kurulmuş köklü annelik idealinin bir modifikasyonu olarak görülebilir. ${ }^{98}$ Tasavvuf literatüründe sadece birkaç örnekte mürşid-mürid ilişkisi anne-çocuk ilişkisine benzetilmiştir. Erken dönem tasavvuf teorisyenleri de kadınlık ve annelik kavramlarını, kişinin mükemmelliğe doğru giden manevi yolculuğunda mücadele etmek zorunda olduğu insandaki alt organlar (lower organs) şeklinde tasvir etmektedir. ${ }^{99} \mathrm{O}$ halde, teorik tasavvufi çerçevede annenin böylesine olumsuz bir imaja sahip olması, gerçekte Bouhdiba'nın “annelerin krallığı" dediği şeye karşı edebi bir tepki olabilir. Annenin çocuğunun seyr u sülûkü üzerindeki fiili etkisine ek olarak, erken dönem zühd ve tasavvuf metinlerinde yer verilen annelere dair ütopik ifadeler ${ }^{100}$ daha sonraki bazı yazarları kısmen Platon'a ait dünyada insanın ruhani önceliği felsefesinden kaynaklanabilecek şekilde, alt ruhun (lower soul) bir sembolü olarak anne ve "kutsal ruh"un (er-ruh el-kudsî) bir sembolü olarak baba hakkında teoriler inşa etmeye motive etmiş olabilir. Galen'in Timaeus özetinde yer alan "erkeklik insanın en iyi doğasıdır" şeklindeki Platonik çerçeve, Huneyn b. İshak tarafından tercüme edilerek, müslüman dünyaya girmiştir. ${ }^{101}$ Kadınlığın aşağı kabul edildiği bu genel görüşün dışında,

98 Robert Briffault, The Mothers: A Study of the Origins of Sentiments and Institutions (New York: Macmillan, 1927), 3/48.

99 bk. Şehâbeddin Sühreverdî, İsimsiz Risale (MS. Cracow: Biblioteka Jagielloński, 3994), 40a-40b; Sühreverdî, Avârifü'l-Maârif, 308-309; bk. Annemarie Schimmel, "The Feminine Element in Sufism”, Mystical Dimensions of Islam, (Chapel Hill: University of North Carolina Press, 1975), 428-429.

100 Oğlunun en önemli refakatçisi ve danışmanı olarak anneler için bk. İbnü'l-Cevzî, Sıfatü's-safve, 3/116-117 [Süfyân es-Sevrî'nin (ö. 161/ 777-78) annesinin, oğluna rızkını sağlarken, oğlunu da kendisini ilme adaması için teşvik ettiği iddia edilmiştir. Bu meyanda, ayrıca bk. Nelly Amri-Laroussi Amri, Les Femmes Soufies ou la Passion de Dieu (St. Jean de Braye: Editions Dangles, 1992), 89. Benzer bir hikaye, hac ziyaretini karşılaması için mirasından oğluna pay vermek isteyen Sülemî’nin annesi hakkında da anlatılmıştır (bk. Sülemî’nin Zikr'inin giriş bölümü, 36). Bir fakihin biyografisinde, annenin oğlunu masasında aynı anda üç çeşit yiyeceğe sahip olmasına karşı uyardığından bahsedilir. (bk. Mâlikî, Riyâdü'n-nufûs, 2/363). Bununla birlikte, zahid nitelikteki bu anneler, erken dönem geleneklerde, oğullarının günlük yaşamlarında elde edebilecekleri güçlü maneviyatı ortaya çıkarmak için edebi bir teknik olarak kullanılmış gibi görünen başka bir türle karşılaştırılmalıdır. Bir hikâyeye göre, Mekkeli Vüheyb bin Verd'in annesi ona içmesi için biraz süt getirmiştir. Bu sütün alındığı keçilerin hükümdarın keçileriyle birlikte otladığından haberdar olan kadın "İç oğlum, Tanrı seni affedecek!" dediğinde bile sütü içmeyi reddeden oğluna gerçeği söylememiștir. (Mekkî, Kūtü'l-kulûb, 2/601.)

101 bk. Huneyn b. İshak, “Cevâmi kitâb Timâvus li-Jâlînûs”, Eflâtun fi'l-İslâm, Abdurrahman el-Bedevî (Tahran: Müessese -i Mütâlaât-i İslâmi, 1974), 95 ve dipnot. 
anneliğin aşağı görüldüğü spesifik bir referans, insanın güneşle ayın, yüce ruhla bedensel varlığın evrensel ilişkisinin mikrokozmozu kabul edildiği felsefi tartışmalarda bulunabilir.102 “Âbâ'una'l-ulviyyât ve ümmahâtuna's-süfliyyât” (ulvî babalarımız ve süflî analarımız/ üstün babalarımız ve aşağı analarımız) ifadesi, müslüman filozofların yazılarında çok sık görülür. ${ }^{103}$ Ancak gerçekte, annelik bağları bu tür soyut tartışmaların kanıtlayabileceğinden çok daha "yüceydi".

Hippolu Augustine için daha derin ve daha bağımsız bir dini deneyim arayışında annesinin refakatinden ayrılmak [bir nevi] 'annenin çocuğunu kendisine yakın tutmak için duyduğu sonsuz arzu' şeklinde tanımladığı şeyden kaçmanın tek yoluydu. ${ }^{104}$ Benzer şekilde Câmî, Abdülkâdir-i Geylânî̀nin (ö. 561/1166) Allah rızası için kendisini serbest bırakması ve Bağdat'a gitmesine izin vermesi için annesine yalvardığını aktarır. Geylânî’nin annesi Ümmü'l-Hayr, kıyamet gününe kadar oğlunu görmeyeceğine dair söz vererek, onun gitmesine izin verir. ${ }^{105}$ Şa'rânî, Muhammed es-Sindâvî’nin sorumluluk sahibi bir evlat olmasına rağmen annesine şöyle dediğini aktarır: "Beni Tanrı'ya bağışla! Bizim buluşmamız ahirette olacaktır”. Yazar şu açıklamayı ekler: “[...] annesinin ona olan düşkünlügünden kaçınmak için" (...li-yakta' tama'ahâ minhu). ${ }^{106}$ Biyografiler ve sûfî tabakatları benzer anekdotlarla doludur. ${ }^{107}$ Açıkça söylemek gerekirse annelerin, oğullarının aile ilişkilerinden kopmasına izin vererek annelik otoritelerinden vazgeçmeye tamamen razı olmaları, başlı başına tasavvuf söyleminin meşhur bir tekniği olan edebi abartıdır.

Mecdüddin el-Bağdâdî'nin biyografisinde, hekim olan annesinin, mürşidinin oğluna davranış biçimine tahammül edemediği söylenmiştir. [Annesi] oğlundan tuvaletleri temiz-

102 bk. İhvân-1 Safâ, Resâ 'ilü İhvâni'ṣ-Ṣafâ, ed. Hayreddin ez-Ziriklî (Kahire: el-Mektebe et-Ticâriyye, 1928), $2 / 379$ (25. risâle). İnsanın evrenin mikrokozmosu olduğuna dair bu teori, İhvân-1 Safâ'nın düşünce sisteminin temelini oluşturuyordu. F. Dieterici, risâlelerin Almanca çevirisinde, orijinal metni iki kısma ayırdı: makrokozmos ve mikrokozmos. bk. F. Dieterici, Die Philosophie der Arabr, IX-ten Jahrhünderten (Leipzig: J.C. Hinrichs, 1858-1895), 8/208.

103 bk. Ebû Hâmid Muhammed el-Gazzâlî, el-Maârifü'l-akliyye, ed. Abdülkerîm Osman (Șam: Dârü'l-fikr, 1963), 21; Muhyiddin İbnü'l-Arabî, “Ukletü'l-Müstevfiz”, Kleinere Schriften des Ibn Al-Arabī, ed. H.S. Nyberg (Leiden: E. J. Brill, 1919), 82.

104 bk. Augustine, Confessions, 82.

105 Câmî, Nefehâtü'l-üns, 507.

106 Abdülvehhâb eş-Şa'rânî, et-Tabakâtü'l-kübrâ (Kahire: el-Matbaa el-Ezheriyye, 1925), 2/165.

107 bk. Câmî, Nefehâtü'l-üns, 520. İbnü'l-Cezerî, ez-Zehru'l-Faih fi Zikri Men Tenezzehe (Kahire: el-Matbaa el-Miligiyye, 1906), 37 (Ebû'l-Hasan es-Sevrî ve annesinin hikayesinde, oğlu annesinden Allah rızası için kendisini serbest bırakmasını istediğinde, annesi şöyle cevap verir: "Ama sende Tanrı için erdemli olan hiçbir şey yok!" Oğlu, annesinin cevabı karşısında şaşırır ve evden ayrılarak beş yıl boyunca inzivada kalır. Daha sonra, kendisine "adanmışlığın nuru" göründüğünde, evine döner ve sonunda annesi onu Allah rızası için özgür bırakmayı kabul eder). Daha sonraki tasavvuf kaynaklarına göre, sûfînin özel hayatındaki en kötü olay sayılabilecek anne ölümü, seyahatlere engel olmayacaktır. bk, İbn Atâullah el-İskenderî, Tertîbü's-sülûk, ed. Halid Zuhrî (Beyrut: Dârü'l-kütübi'l-ilmiyye, 2004), 22. 
lemesinin istendiğini öğrendiğinde, onun yerine Türk kölelerini göndermeyi teklif etmiştir. Hikayeye göre, şeyh kabul etmemiş ve [şöyle demiştir]: "eğer ben bir hekim, oğlunuz da hasta ise ilacı Türk köleye verdiğim takdirde oğlunuz iyileşmeyecektir!"108 Kanaatimce böyle bir hikaye, çoğunlukla özellikle erken dönemlerinde tasavvufun kuramsal sistemine uyması için son derece ideal terimlerle tasvir edilen, tipik ve (modern terminolojiyi kullanırsak) "özcü" annelik hakkında yukarıda bahsedilen anekdotlardan daha güvenilirdir. Bunun yanı sıra, Mekke'de uzun süre kalan (mücâvir) kadın sûfîler ve erkek sûfîlerin evinde gecelemekten çekinmeyen diğer kadınlarla ilgili hikayelerin güvenilir olup olmadığı ve bu kadınların bekâr mı yoksa anne ve eş mi olduğu açık değildir. ${ }^{109}$ Tasavvuf tabakatlarında, Zünnûn Mısrînnin (ö. 245/860) “erkek” hocası (üstadı) ${ }^{110}$ olarak tanınan Nîşâburlu Fâtıma (ö. 232/846), hayatını uzun bir mücâvere içinde geçirmiş ve biyografik kayıtlarının hiçbirinde ailevi durumu açıç̧a belirtilmemiştir.

Diğer birçok durumda, dindar kadınlar anneydi ve erkek sûfîlerle diğer kadınların gerçekten hoşnut olmayacağı belli bir dereceye kadar serbestçe dolaşmaktan ve ilişki kurmaktan hoşnut kalmış görünüyorlardı. Durum böyleyse, bu tür kadınların çocuklarının, annelerinin dindarlığının doğrudan etkisi altına girmelerinin beklendiğini düşünüyorum. Bununla birlikte, çocuklar bağımsız olarak kendi maneviyatlarını/dindarlıklarını ortaya koymayı başardıklarında ve kendilerine ait bağımsız bir tasavvufi yol aramaya can attıklarında, anneleri bu konudan tam olarak "etkilenmiş" görünmemekte ve "anne otoritesi", mutlak anne desteğinin önüne geçmiş gibi durmaktadır. Modern dönemde yapılan son tasavvuf araştırmaları, sûfî çevrelerde annelerin çocuklarının tarikatlara ve velilere olan bağlılığıyla ne ölçüde ilgilendiklerini göstermiștir; anneler oğulları hakkında karar verme hususuyla oldukça ilgiliyken babalar, çocuklarının kendi kararlarını verecek kadar olgunlaştı̆̆ı sonraki yıllara kadar tarikatlarla aktif bağlara ilgi duymaz. ${ }^{111}$

108 bk. Câmî, Nefehâtü'l-üns, 424.

109 Örneğin, erkek yoldaşları evinde geceleyen Ubullalı Reyhâne'nin biyografisi için bk. (İbnü'l-Cevzî, Sıfatü's-safve, 4/38; Sulamī, Dhikr, 307). Câmî, Necîbüddin b. Büzgaş'ın (ö. 678/1280) evinde geceleyen İranlı isimsiz bir kadından bahseder: bk. Câmî, Nefehâtü'l-üns, 634 .

$110 \mathrm{Bu}$ kelime, erkek varyasyonunda Sülemî tarafından istisnai dindar kadınları rûhâni erkeklerin statüsüne yükselten sûfî geleneğini belirtmek için kullanılmıştır. bk. Sulamī, Dhikr, 43; Not. 108. Sülemî’nin kitabının ilk muhakkiki Mısırlı Mahmud et-Tânâhî için, bu örnekler yalnızca "dilbilimsel bir anomali” gösterir [Sulamī, Dhikr, ed. Mahmud et-Tânâhî (Kahire: y.y, 1993), giriş bölümü, 19].

111 bk. Daisy Dwyer, "Women, Sufism, and Decision-Making in Moroccan Islam", Women in the Muslim World, ed. Lois Beck and Nikki Keddie (Cambridge: Harvard University Press, 1978), 596-597. 


\section{Sûfî Tabakatlarında Dayılar}

Sûfî tabakatlarında sıklıkla, dayılar yeğenlerinin seyr u sülûklerinde temel bir rol oynarlar. İyi bilinen örnekler; Cüneyd-i Bağdâdî ve dayısı Serî es-Sakatî, ${ }^{112}$ Abdülvâhid esSeyyârî (ö. 375/985) ve dayısı Ebû'l-Abbâs es-Seyyârî (ö. 342/953)113, Sehl et-Tüsterî ve Muhammed b. Savvâr, ${ }^{114}$ Ebû Abdullah er-Rûzbârî (ö. 369/979) ve meşhur dayısı Ebû Ali er -Rûzbârî'dir (ö. 322/933). Sonuncusunun yukarıda adı geçen kız kardeşi, oğlunun sadece dindar bir adam, erkek kardeşinin ise gerçek bir sûfî olduğuna inanmış ve bu nedenle oğlundan dayısının davranışlarını taklit etmesini istemiştir. ${ }^{115}$ Annelerin aksine, sûfî dayılar büyük olasılıkla yeğenleri için güçlü bir tetikleyiciydi. Kadim anaerkil toplumlarda kız kardeşlerin, kız kardeşlerin ailelerinin ve çocuklarının doğal destekçileri ve koruyucusu olanlar, babalar ya da kocalar değil, erkek kardeşlerdi. Ataerkil yapı daha ilkel anaerkilliğin yerini almış olmasına rağmen, ilkel toplumun bu birincil özelliği, hem kadim toplumlarda hem de modern medeniyetlerde farklı şekillerde varlığını sürdürmektedir. ${ }^{116}$ Bizim bağlamımızda da olduğu gibi, farklı kültürlerde yapılan antropolojik çalışmalarda eşler ve kız evlatlardan ziyade kız kardeşler ve anneler, yüksek bir sosyal statüye sahip olan ve dolayısıyla etkili ve dikkate değer roller oynayabilen kadınlar olarak görülür.117 Sûfî tabakatlarında, tanınmışs sûfî kardeşlerini güçlü bir şekilde destekleyen kız kardeşleri görürüz. Bu kız kardeşlerin bir kısmı, erkek kardeşlerine "hizmet etmek" için ileri yaşlara kadar evlenmemeyi tercih ederken, ${ }^{118}$ diğerleri kendi seyr u sülûklerini sürdürürken kardeşlerine destek olmuştur. ${ }^{119} \mathrm{Bu}$ türden verileri değerlendirirken, zaman ve mekânın tarihsel bağlamdaki yerine dikkat ederim. Burada bahsi geçen kadınlar, sosyal normlara veya yasaklara rağmen erkek kardeşlerini veya erkek akrabalarını korumaya çalışan ve kuşkusuz onla-

112 bk. Kușeyrî, Risâle, 10, 20; Sülemî, Tabakātü'ș-șûfiyye, 141. Ayrıca bk. Sülemî, Tabakātü'ṣ-ṣ̂fiyye, 41-48 (Cüneyd'in dönüşümünde Sakatî'nin tasavvufi söylemleri ve doktrinleri üzerine).

113 Câmî, Nefehâtü'l-üns, 145-146.

114 Kuşeyrî, Risâle, 15-16.

115 Sulamī, Dhikr, 214; Câmî, Nefehâtü'l-üns, 265.

116 bk. Briffault, The Mothers, 1/498; Margaret Smith, Muslim Women Mystics: The Life and Work of Rābi ' $a$ and other Women Mystics in Islam (Oxford: Oneworld, 2001), 141-142. Roma İmparatorluğu'nda anasoylu bağların önemi üzerine bk. Herlihy, Medieval Households, 6-7.

117 bk. Susan Sered, "Mothers and Icons", Nashim: A Journal of Jewish Women's Studies and Gender Issues 3 (2000), 11. Erken dönem İslam tarihinde kız kardeşlerin sahip olduğu güçlü etkinin bir örneği, İbn Asâkir'in yer verdiği, Emevi halifesi Muaviye'ye kardeşi Abdullah b. Emir'i şikayet eden/lanetleyen kadına ait biyografide görülür. Muaviye atına binmek istediğinde, Abdullah onu halifeyi durdurabilen ve tartışırken onu alt edebilen bu kadına karşı uyarmıştır. [bk. İbn Asâkir, Ta'rih (terâcimu'n-nisâ), 566].

118 bk. Câmî, Nefehâtü'l-üns, 325.

119 bk. Sulamī, Dhikr, 123, 193, 195, 217. 
ra güçlü bir otorite veren, çoğunlukla evli kadınlardır. Anaerkil sistemin bir yönü olan bu yakın aile bağlarından yola çıkarak, sûfî tabakatlarındaki dayıların yeğenleri üzerinde önemli bir etkiye sahip olduğunu söyleyebiliriz. Dayıların, yeğenlerinin tasavvuf yolculuğu üzerindeki ilham verici etkisi, destekleyici annelik ideallerinin ve güçlü bir anne desteğinin sadece annelikten daha etkili olduğu aktif bir alan olarak düşünülmelidir.

\section{Sonuç}

Din psikologları genellikle “dini yaşantının/sorumlulukların ve anneliğin birlikte yürüdüğünü" varsayarlar. ${ }^{120}$ İslam'da annelik, eşlik gibi kurumsal olarak vurgulanmasa da son derece saygın bir konuma sahiptir. ${ }^{121}$ Dahası tasavvufta, annelerin onuru dini ahlakla ilişkilendirilmiş ve bu nedenle tasavvufi yaşantının zühdi boyutunun kendini gösterdiği temel alan olmuştur. Bu, anneliğin “geleneksel değerlerinin” ümmetin işbirliğine dayalı topluluk yaşamının İslami değerlerine güçlü bir şekilde karşılık geldiğini gösterir. Muhakkak ki ümmetin etimolojik kökeni, anneliğin İslam'daki hayati konumunu ifade eder (Arapça'da ümm anne anlamına gelir).

İslam tasavvufunda, anneliğin iki ayrı âlemden oluştuğu düşünülmelidir: ilki gerçek anneliktir, diğeri ise teorik ve edebi söylemin bir parçası olan sembolik anneliği ifade eder. Alt ruhun sembolü olan anneliğin, annelerin çocuklarının manevi yaşamlarında oynadıkları etkili rollerle hiçbir ilgisi yoktur. Bu bakımdan, kendileri de sûfî olan anneler ile sûfîlerin annesi olan anneleri birbirinden ayırmalıyız. Büyük olasılıkla, her iki tipte de annelerin her zaman tartışmasız etkili, güçlü bir tetikleyici olmadığı görülmektedir. Bazı durumlarda, tanınmış sûfîlerin anneleri, annenin rızasını alma ilkesinden ve anne hakkından yararlanarak, oğullarının serbestçe seyahat etmesine engel olmuştur. Farklı kaynaklardan elde edilen verilerden yararlanmak, birçok sûfînin bağımsız yaşamlarını kurmak için aslında annelerinin otoritesini azaltmaya çalıştıkları iddiasına yol açmaktadır. Kanaatimce bu durum "Cennet, annelerin ayaklarının altındadır” şeklindeki meşhur hadisin, kişinin annesine [sağladığ1] sonu gelmeyen bakım ve desteği içeren basit manasının ötesine geçtiğini ve

120 Sered, "Mothers and Icons", 10.

121 Kur'ânî düzende ebeveyne bağlılık, açıkça, Tanrı'ya kulluktan sonradır. (el-Bakara 2/83; en-Nisâ 4/36; el-En'âm 6/151; el-İsrâ 17/23). Bu tutum, en iyi șekilde Hz. İsa'nın şu sözleriyle gösterilen hıristiyan öğretileriyle karşılaştırılmalıdır: "Babasını ve annesini benden daha çok seven bana layık değildir" (Matta, 11.37). Herlihy, "dini hayata ailelerinin katı muhalefetiyle giren" Orta Çağ hıristiyan azizlerinin hemen hemen her zaman "bekar, dul, çoğu zaman terk edilmiş kişiler [rûhâni deneyimlerle iç huzur arayanlar/aile eksikliğini telafi etmeye çalışanlar]" olduğunu savunur. bk. Herlihy, Medieval Households, 114-115. 
Nizâmeddin Evliyâ (ö. 725/1325) için de söylendiği gibi, annelerin çocuklarını bazen fiziksel olarak dahi nasıl boyun eğdirmeyi başardığını gösterir. ${ }^{122}$

Hem en uç haliyle annelik onurunu [koruma] idealini hem de kelimenin tam anlamıyla aile bağlarının kopması ve sorumluluklardan uzaklaşma anlamına gelen Tanrı'ya mutlak adanma doktrinini [münzevi yaşamı], uzlaşmaz bir şekilde içeren erken dönem tasavvufudur. Bazı modern çalışmalarda ${ }^{123}$ da görülebileceği gibi bu çalışmada, "eşlerin ve annelerin, Tanrı'ya ulaşma yolunda kendi yolculuklarına devam ederken aile üyelerine destek vermelerinin" annelik kurumunun bir başka "geleneksel” yönü olduğu düşüncesini savundum ancak çoğu durumda bu, annelerin (sûfî evlatların sûfî olmayan anneleri veya sûfî olan ya da olmayan evlatların sûfî anneleri) hakikatte ne olduklarına dair bir fikir vermez. Hıristiyanlık'ta Meryem'in kutsal imgesi, bebek İsa kültü ve geç Orta Çağ'ın kadın azizlerinin haleflerine ruhani bir annelik iddiasında bulunma biçimleri124 adanmışlık ve kutsallık söz konusu olduğunda, bu ikonik "aziz annelik" hayalini pekiştirmeye katkıda bulunmuştur. Literatürde ve tarihyazımında, tahtlarına sahip çıkmak için oğullarını öldüren veya oğullarını miraslarından mahrum bırakan annelere dair deliller aranabilir, ancak bu tür vakalar nadirdir. ${ }^{125}$ Sûfî anneliğiyle ilgili genellemeleri çürütmek için bu tür aşırı anekdotlar üzerinde durmuyorum, tıpkı diğer alanlarda olduğu gibi tasavvuf alanında da bu konunun, uyumlu, hakiki, aziz ve ikonik/geleneksel bir kurum olarak annelikle ilgili abartılı düşüncelerden uzak tutulması gerektiğini savunuyorum.

Zamanla, sûfilerin inziva ve bütünüyle adanma doktrinleri bizzat sûfîler tarafindan yeniden ele alınmıştır. Erken klasik dönemin sonunda, sûfî "kardeşliği" içinde ve dışında ayrıntılı yönlendirmeler ve kapsamlı davranış modelleriyle desteklenen sûfî grupların kolektif yaşamı, inziva ve halvetle (tam manasıyla adanma) rekabet edebilirdi. Sonuç olarak, daha sonra bir silsile veya tarikat olarak bilinen sûfî topluluklarına disiplinli bağlllık, kişinin aile bağlarından büyük ölçüde vazgeçip, "manevi aile"sini benimsemesini gerektir-

122 Nizâmeddin Evliyâ'nın (ö. 725/1325), yeni ay için duasını alabilmek amacıyla annesinin ayaklarına kapandığı söylenir. bk. Schimmel, My Soul is a Woman, 91.

123 Camille Helminski, Women of Sufism: a Hidden Treasure (Boston: Shambhala, 2003), 25.

124 Bu bağlamda, bk. Herlihy, Medieval Households, 120-124.

125 bk. Herlihy, Medieval Households, 124-125. İslam tarihinde bk. Sehâvî, Mu'cemu'n-nisâ, 12 (en büyük oğlundan hoşnut olmadığı söylenen Bedriye adında bir kadın üzerine: "se'hıtâ alâ ekber evlâdihâ); İzzeddin İbnü'l-Esîr, elKâmil fi't-tarih (Beyrut: Dâr Sâdir, 1966), 11/55 (Zümrüd Hatun hakkında). bk. Muhammed el-A lamî, Terâcim aâlâm en-nisâ (Beyrut: Müessesetü'l-Alamî, 1987), 1/236 (Ümmü’l-Asvâr), 237 (Ümmü Af' â). 
miştir. Bu tür gelişmelerin sonraki tasavvuf literatüründe anne imajını etkileyip etkilemediğinden ve kurumsallaşmış geniş bir tasavvufi yaşamın ışığında otoritesini yitirmesi beklenen anneliğin, dişil alt güçlerin edebi imgelerinde giderek daha geniş bir yer kaplayan teorik bir kadınlık lehine ortadan kaybolup kaybolmadığından emin değilim. Bu aşamada, tatmin edici cevaplara ulaşamasak bile, bu soruları akılda tutmak yararlı olacaktır.

Tasavvufi bağlamda anneler, "ister anılmayacak kadar önemsiz [görülmüş], ister aleniyetin göz kamaştırıcı ve kutsallıktan uzak ışı̆̆ının altına getirilmek için çok kutsal ve uygunsuz kabul edilmiş olsun"126 [bu konuya dair] literatürdeki ihmal payının olumsuz bir tutum anlamına gelmediğine inanıyorum. "Literatürdeki bu ihmal" sayesinde sûfî kadın ve anneler, kendilerini "rûhâni erkekler" olarak kabul ederek sûfî yaşantısının kendilerine sunacaklarının tadını çıkarabilirler. ${ }^{127}$ Annelik ve tasavvuf kavramlarıyla uğraşırken geleneksel imgelerden kaçınarak, annelerin göğüslerinin hem sütün hem de kanın uyumlu bir şekilde birbirine karıştığı yer olarak tanımlanmasından yararlanmak çok kaba olmayacaktır. Diğer yandan, değişken ve ikircikli tasavvufi düşünce sistemi, anne onurunun belirleyici bir konuma sahip olduğu aşırı dini ahlakın temellerini oluştururken, tanımı gereği “annelerin krallı̆̆ı”na yönelik zımni bir tehdit içermiştir.

126 Mohammad Wahid Mirza, The Life and Works of Amir Khusrau (Lahore: Panjab University Press, 1962), 17.

127 Bâyezîd'in Ahmed b. Hadraveyh'in eşi Fâtıma hakkındaki tanımı için bk. "Kadın giysileri içinde gizlenen bir er görmek isteyene izin verin Fâtıma'ya baksın!" Hujwīrī, Kashf al-mahjūb, 120; 'Attạr, Tadhkirat al-awliyā, 1/289, str. 16-17. 


\section{Kaynakça}

A 'lamî, Muhammed. Terâcim aâlâm en-nisâ. Beyrut: Müessesetü'l-Alamî, 1987.

Amri, Nelly- Laroussi, Amri. Les Femmes Soufies ou la Passion de Dieu. St. Jean de Braye: Editions Dangles, 1992.

'Attar, Farīd al-Dīn. Tadhkirat al-awliyā') ed. R.A. Nicholson. Leiden: Brill, 1905.

'Attar, Farīd al-Dīn. Muslim Saints and Mystics: Episodes from the Tadhkirat al-awliyā' (Evliyâ Tezkireleri). çev.: A.J. Arberry. London: Routledge \& Kegan Paul, 1966.

(Saint) Augustine. Confessions. çev. Henry Chadwick. Oxford: Oxford University Press, 1998.

Bouhdiba, Abdelwahab. "In the Kingdom of the Mothers". çev. Alan Sheridan. Sexuality in Islam. ed. Bouhdiba Abdelwahab. 212-230. Londra, Boston, Melbourne \& Henley: Routledge \& Kegan Paul, 1985.

Briffault, Robert. The Mothers: A Study of the Origins of Sentiments and Institutions. New York: Macmillan, 1927.

Buhârî, Muhammad b. İsmâil. Sạhîh el-Buhârî. Beyrut: Dârü'l-kütübi'l-ilmiyye, 2001.

Câmî, Abdurrahman. Nefehâtü'l-üns. ed. Mehdî Pur. Tahran: Intișârât-1 kitâbfurûşî Mahmûdî, 1918.

Cüneyd Şîrâzî, Muînüddîn. Şeddü'l-izâr fî hațți'l-evzâr 'an züvvâri'l-mezâr. ed. Muhammed Kazvînî- Abbas İkbâl. Tahran: Çaphâne-i Meclis, 1949.

Deylemî, Ali b. Muhammed b. Hasan. Sîret İbn Hafîf eş-Şirazî. çev. Yahya b. Cüneyd eşŞirazî- İbrahim ed-Desûkî Şatâ. Kahire: Mecmu’ el-buhûs el-İslâmiyye, 1977.

Dieterici, F. Die Philosophie der Arabern im IX-ten Jahrhünderten. Leipzig: J.C. Hinrichs, 1858-1895.

Dwyer, Daisy. "Women, Sufism, and Decision-Making in Moroccan Islam". Women in the Muslim World. ed. Lois Beck and Nikki Keddie. 585-598. Cambridge: Harvard University Press, 1978.

Ebn-e Monavvar, Mohammad. The Secrets of God's Mystical Oneness or The Spiritual Stations of Sheikh Abu Sa'id [Esrârü't-Tevhîd fî Makâmâti'ş-Şeyh Ebû Saîd']. çev. John O’Kane. Costa Mesa, CA \& New York: Mazda Publishers, 1992.

Gazzâlî, Ebû Hâmid Muhammed. İhyâü Ulûmi’d-dîn. Kahire: Dârü'l-Menâr, ts. 
Gazzâlî, Ebû Hâmid Muhammed. el-Maârifü'l-akliyye. ed. Abdülkerîm Osman. Şam: Dârü'l fikr, 1963.

Gramlich, Richard. Alte Vorbilder des Sufitums. Wiesbaden: Harrassowitz Verlag, 1996.

Helminski, Camille. Women of Sufism: a Hidden Treasure. Boston: Shambhala, 2003.

Herlihy, David. Medieval Households. Cambridge: Harvard University Press, 1985.

Hindî, Müttakī. Kenzü'l-‘ummâl fî süneni'l-akvâl ve'l-ef'âl. Haydarâbâd-ed-Dukn: Dâirât el-Maârif el-Osmaniyye, 1974.

Huneyn b. İshak. “Cevâmi kitâb Timâvus li-Jâlînûs”. Eflâtun fi'l-İslâm. Abdurrahman elBedevî. Tahran: Müessese-i Mütâlaât-i İslâmi, 1974.

Hujwīrī al-Jullābī, Alī b. 'Uthmān. The Kashf al-Mahjūb. çev. R.A. Nicholson. Londra: E.J.W. Gibb Memorial \& Luzac, 1976.

İbn Asâkir, Ebü'l-Kâsım Alî b. Hasen. Târîhu medîneti Dımaşk: terâcimu'n-nisâ, ed. Sukayna al-Shihābī. Şam: Dârü'l-fikr, 1981.

İbn Hamîs el-Mevsılî. Menâkıbü'l-ebrâr ve mehâsinü'l-ahyâr. ed. Said Abdülfettâh. Beyrut: Dârü'l-kütübi'l-ilmiyye, 2006.

İbn Manzûr, Mükerrem. Muḩtașaru Târîhi Dımaşk. ed. Ma'mûn es-Segercî. Şam: Dârü'lfikr, 1984.

İbnü'l-Arabî, Muhyiddin. “Ukletü'l-Müstevfiz”. Kleinere Schriften des Ibn Al-Arabī. ed. H.S. Nyberg. Leiden: E. J. Brill, 1919.

İbnü'l-Cevzî, Ebü'l-Ferec Abdurrahmân. Sifatü's-safve, Haydarâbâd: Meclis Dâirâtü'lMaârif el-Osmaniyye, 1968-1972.

İbnü'l-Cevzî, Ebü'l-Ferec Abdurrahmân. Birru'l-vâlideyn. ed. Muhammed Abdülkâdir Atâ.

Beyrut: Müessese el-Kütübi’s-Sekâfiyye, 1988.

İbnü'l-Cevzî, Ebü'l-Ferec Abdurrahmân. Ahbâru'n-nisâ. ed. Ahmed b. Ali. Kahire: Dârü'lMenâr, 1998.

İbnü'l-Cezerî. ez-Zehru'l-Faih fi Zikri Men Tenezzehe. Kahire: el-Matbaa el-Miligiyye, 1906. İbnü'l-Esîr, İzzeddin. el-Kâmil fi't-tarih. Beyrut: Dâr Sâdir, 1966.

İbnü'l-Esîr, İzzeddin. Üsdü'l-ġābe fî ma‘rifeti’ṣ-ṣahâbe. ed. Muhammed el-Bennâ vd. b.y:y.y, 1970. 
İbnü'z-Zeyyât, Yusuf b. Yahya. et-Teşevvüf ilâ Ricâli't-Tasavvuf. ed. Ahmed Tevfik. Ribât: Menşûrât Külliyyeti'l-Âdâb, 1997.

İhvân-1 Safâ. Resâ’ilü İhvâni’s-Safâ. ed. Hayreddin ez-Ziriklî. Kahire: el-Mektebe etTicâriyye, 1928.

İsfahânî, Ebû Nuaym. Ḥilyetü'l-evliyâ' ve țabakātü'l-aṣfiyâ'. ed. Mustafa Abdülkâdir ‘Atâ. Beyrut: Dârü’l-kütübi’l-ilmiyye, 1997.

İskenderî, İbn Atâullah. Tertîbü's-sülûk, ed. Halid Zuhrî. Beyrut: Dârü'l-kütübi'l-ilmiyye, 2004.

Johnson, Miriam M. Strong Mothers, Weak Wives: The Search for Gender Equality. Berkeley, Los Angeles \& Londra: University of California Press, 1988.

Kâşânî, İzzeddin Mahmud. Misbâh el-hidâye ve-miftâh el-kifâye. ed. Celâleddin Humâyî. Tahran: Müessese-i Naşrihumâ, 2002.

Kubrā, Najm al-Dīn. Fawā’ih al-jamāl wa-fawātih al-jalāl. ed. Fritz Meier. Wiesbaden: Franz Steiner Verlag, 1957.

Kurtubî, Muhammed b. Ahmed. el-Câmi li-ahkâm el-Kur'ân. Beyrut: Dârü’l-fikr, 1993.

Kuşeyrî, Abdülkerîm. er-Risâle el-Kuşeyrîyye. Kahire: el-Bâbî el-Halabî, 1940.

Longhurst, Robyn. Maternities: Gender, Bodies and Space. New York: Routledge, 2008.

Mâlikî, Ebûbekir Abdullah b. Muhammed. Riyâdü'n-nufûs fi Tabakât Ulemâi'l-Kayruvan ve İfrikiyye ve Zühhâdihim ve-Nussâkihim ve-Siyer min Ahbârihim ve-fedâilihim veevsâfihim. ed. Başîr el-Bakkûş. Beyrut: Dârü'l-garb el-İslâmi, 1983.

Meier, Fritz. "The Mystic Path”. The World of Islam: Faith, People, Culture. ed. Bernard Lewis. 117-140. London: Thames \& Hudson, 1976.

Mekkî, Ebû Tâlib. Kūtü'l-kulûb. Kahire: Mușțafā al-Bābī al-Ḥalabī, 1961.

Mernissi, Fatima. "Women in Muslim History: Traditional Perspectives and New Strategies". Women and Islam: Critical Concepts in Sociology. ed. Haideh Moghissi. 1/37-52. Londra: Routledge, 2005.

Mirza, Mohammad Wahid. The Life and Works of Amir Khusrau. Lahore: Panjab University Press, 1962.

Muâfâ b. İmrân. Kitâbü'z-Zühd. ed. Âmir Sabrî. Beyrut: Dârü'l-Beşâirü'l-İslâmiyye, 1999. 
Nevevî, Yahyâ b. Şerefeddin. Riyâzü’s-Sâlihîn min kelâm seyyîd el-mürselin. Kahire: Mektebet Misir, 1995.

Nurbaksh, Javad. Sufi Women. New York: Khaniqāhi-Ni`matullāhī Publications, 1983.

Rapoport, Yossef. Marriage, Money, and Divorce in Medieval Islamic Society. Cambridge: Cambridge University Press, 2005.

Ritter, Hellmut. The Ocean of the Soul: Man, the World and God in the Stories of Farīd alDīn ‘Atțạ̄r. çev. Bernd Radtke-John O’Kane. Leiden and Boston: Brill, 2003.

Salamah-Qudsi, Arin. "Institutionalized Mashyakha in the Twelfth Century Sufism of 'Umar al-Suhrawardī”. Jerusalem Studies in Arabic and Islam 36 (2009), 381424.

Salamah-Qudsi, Arin. "The Idea of Tashabbuh in Sufi Communities and Literature of the Late 6th/12th and Early 7th/13th Century in Baghdad". al-Qantạra 32/1 (2011), 175197.

Sarrāj, Abū Naș̣. Al-Luma` fïl-tasạwwuf, ed. R.A. Nicholson. Leiden: Brill, 1914.

Schimmel, Annemarie. Mystical Dimensions of Islam. Chapel Hill: University of North Carolina Press, 1975.

Schimmel, Annemarie. "The Feminine Element in Sufism”. Mystical Dimensions of Islam. Annemarie Schimmel. 426-435. Chapel Hill: University of North Carolina Press, 1975.

Schimmel, Annemarie. "Eros in Sufi Literature and Life". Society and the Sexes in Medieval Islam. ed. Afaf Lutfi al-Sayyid-Marsot. 119-141. Malibu: Undena Publications, 1979.

Schimmel, Annemarie. "Women in Mystical Islam”. Women and Islam. ed. Aziza al-Hibri. 145-151. Oxford: Pergamon Press, 1982.

Schimmel, Annemarie. My Soul is a Woman: the Feminine in Islam. çev. Susan H. Ray. New York: Continuum, 1997.

Sehâvî, Muhammed b. Abdirrahmân. eḍ-Ḍav'ü'l-lâmi' li-ehli'l karni't-tâsi. Beyrut: Dâr Mektebetü'l-hayâ, ts.

Sehlegî. en-Nûr min Kelimâti Ebî’t-Tayfûr, Şatahât es-sûfiyye. ed. Abdurrahman Bedevî. Kuveyt: Vekâlet el-matbuat, 1976.

Sered, Susan. "Mothers and Icons". Nashim: A Journal of Jewish Women's Studies and gender Issues 3 (2000), 5-14. 
Smith, Margaret. Muslim Women Mystics: The Life and Work of Rābica and other Women Mystics in Islam. Oxford: Oneworld, 2001.

Sulamī, Abū'Abd ar-Rahmān. Early Sufi Women: Dhikr an-niswa al-mutacabbidāt as. sufiyyāt. çev. Rkia E. Cornell. Louisville: Fons Vitae, 1999.

Sühreverdî, Şehâbeddin. İsimsiz Risale. MS. Cracow: Biblioteka Jagielloński, 3994, $25 b-85 b$.

Sühreverdî, Şehâbeddin. Avârifü'l-Maârif. (Ebû Hâmid el-Gazzâlî, İhyâü Ulûmi'd-dîn içinde). Kahire: El-Bâbi el-Halabî, 1967.

Sülemî, Ebû Abdirrahmân. Kitâbü'l-Erbaîn fï’t-Tasavvuf. Haydarâbâd: Meclis Dâirât elMaârif el-Osmaniyye, 1950

Sülemî, Ebû Abdirrahmân. Ṭabakātü'ṣ-ṣûfiyye. ed. Johannes Pedersen. Leiden: Brill, 1960.

Şa'rânî, Abdülvehhâb. et-Tabakâtü'l-kübrâ. Kahire: el-Matbaa el-Ezheriyye, 1925.

Tartûsî, Ebûbekir Muhammed b. El-Velîd. Birru'l-vâlideyn: mâ yecib alâ'l-vâlid liveledihi ve-mâ yecib alâ'l-veled li-vâlidihi. ed. Muhammed Abdülkerîm elKâd1. Beyrut: Müessese el-Kütübi’s-Sekâfiyye, 1986.

Tirmizî, Muhammed b. İsâ. el-Câmi el-kebîr. ed. Başşâr Ma'rûf. Beyrut: Dârü’l-garb elİslâmi, 1998.

Yasushi, Tonaga. "Sufism in the Past and Present". Annals of Japan Association of Middle East Studies 21 (2006), 7-21. 